\title{
Activated Microglia in the Brain: Mitochondrial and Cell Membrane-Associated Targets for Positron Emission Tomography*
}

\author{
Margit Pissarek \\ Forschungszentrum Jülich GmbH, Institute of Neurosciences and Medicine, INM5-Nuclear Chemistry, Jülich, Germany \\ Email: m.pissarek@fz-juelich.de
}

How to cite this paper: Pissarek, M. (2018) Activated Microglia in the Brain: Mitochondrial and Cell Membrane-Associated Targets for Positron Emission Tomography. World Journal of Neuroscience, 8, 50-81. https://doi.org/10.4236/wjns.2018.81006

Received: November 27, 2017

Accepted: January 28, 2018

Published: January 31, 2018

Copyright $\odot 2018$ by author and Scientific Research Publishing Inc. This work is licensed under the Creative Commons Attribution International License (CC BY 4.0).

http://creativecommons.org/licenses/by/4.0/

\section{c) (i) Open Access}

\begin{abstract}
The emission tomographic imaging of activated microglia in the brain moves into the focus of neuroscientific research with increasing recognition of contributions of early inflammatory processes to neurodegenerative, traumatic, cancerous and infectious diseases of the brain. Whereas the mitochondrial isoform of the $18 \mathrm{kDa}$ translocator protein (TSPO1) has been the main cellular target for positron emission tomography (PET) of this type of cells for decades, alternative marker proteins in the plasma membrane of microglia challenge efforts in ligand development, recently. The present report includes PET approaches using the chemokine receptor CX3CR1 and the FR2 folate receptor in parallel to small molecule PET tracers available for in vivo visualization of the "classical" target TSPO1. It compares first and second generation of TSPO1 ligands as well as new compounds like the tetrahydrocarbazole $\left[{ }^{18} \mathrm{~F}\right] \mathrm{GE}-180$ and the quinazoline $\left[{ }^{11} \mathrm{C}\right] \mathrm{ER} 176$ presumed to reduce polymorphism-related inter-subject variations, with allosteric ligands for the chemokine receptor CX3CR1 and with radio labelled folate conjugates targeting the folate "cargo" receptor FR1 and the FR2 receptor characteristic for anti-inflammatory M2 microglia.
\end{abstract}

\section{Keywords}

Microglia, Inflammation, Brain, PET, TSPO, CX3CR1, Folate Receptor

\section{Introduction}

The imaging of microglia as a marker of inflammation in traumatic, degenerative, neuropsychiatric and infectious brain diseases has been already for years a

${ }^{\star}$ Brain PET of activated Microglia 
surrogate method for the monitoring of cerebral disorders [1]. The resting/surveying microglia in healthy tissue (resident macrophages of the brain) communicates with adjacent neurons and glia cells [2]. Cross talk between microglia and neurons is presumed to play an important role for synaptic plasticity [3] [4] [5] [6] [7]. Microglia can be activated by diverse molecules released during pathological alterations and reacts adopting different activated phenotypes [2] [8] [9] [10] [11]. Recently, microglial activation is regarded as one of the initial factors turning early acute metabolic and structural alterations into chronic processes.

Microglia acts as immune cell by survey of environmental and micro-environmental factors [5] [12] [13] [14]. The two extreme, functional kinds of possible phenotypes of activated microglia are M1 cells (classically activated, inflammatory) and M2 cells (alternatively activated, anti-inflammatory) [9] [15].

For immunological approaches, such polarization of the functionality of microglia corresponds to the actions of the subsets of $\mathrm{T}$ helper cells (CD4 cells), Th1 and Th2 lymphocytes releasing the respective Th1-type and Th2-type cytokines as pro-inflammatory or anti-inflammatory response [10] [15] [16].

Microglia accounts for $5 \%-10 \%$ of total glia cells of the human brain [10] [16] [17] and up to $20 \%$ in other mammalian species [18] [19] with lower percentage in the cortex and higher in corpus callosum. $30 \%-50 \%$ of cells in glioma are microglial cells; and glioma and astrocytoma are the most common brain tumors [20].

Investigations of typical microglial cells are limited in vitro, because the source of this cell population in the brain is, as widely accepted, the yolk sac releasing a wave of primitive macrophages as progenitor cells of microglia during the early embryonal development [21] [22] [23] [24]. Microglial population colonizes the whole CNS and maintains itself by local proliferation [23] [24].

A postnatal supplement of the resident cerebral microglial population by macrophages from the circulation is not very probably but also not completely out of discussion [24] [25]. As the normal functional state of microglia is accepted the resting (surveying) state [5].

Currently, a multitude of structural markers is known allowing immunohistological phenotyping of microglia of different shapes, functions and locations [26] in vitro or ex vivo.

For in vivo imaging, one of the main targets investigated with PET or SPECT in microglial cells has been for many years mitochondrial TSPO1 (translocator protein $18 \mathrm{kDa}$ ), the former peripheral benzodiazepine binding sites (PBR) [27], overexpressed in activated microglia.

Recently, efforts of developing PET tracers move also to markers of the plasma membrane, particularly, to the chemokine receptor CX3CR1, which plays a central role in the cross talk between neurons and microglia [6] [28] [29], as well as to the FR2 subtype of the folate receptor (see Figure 1) [30].

First compounds investigated as TSPO ligands potentially useful as PET tracer were benzodiazepines [27], followed by non-benzodiazepines of several generations. 


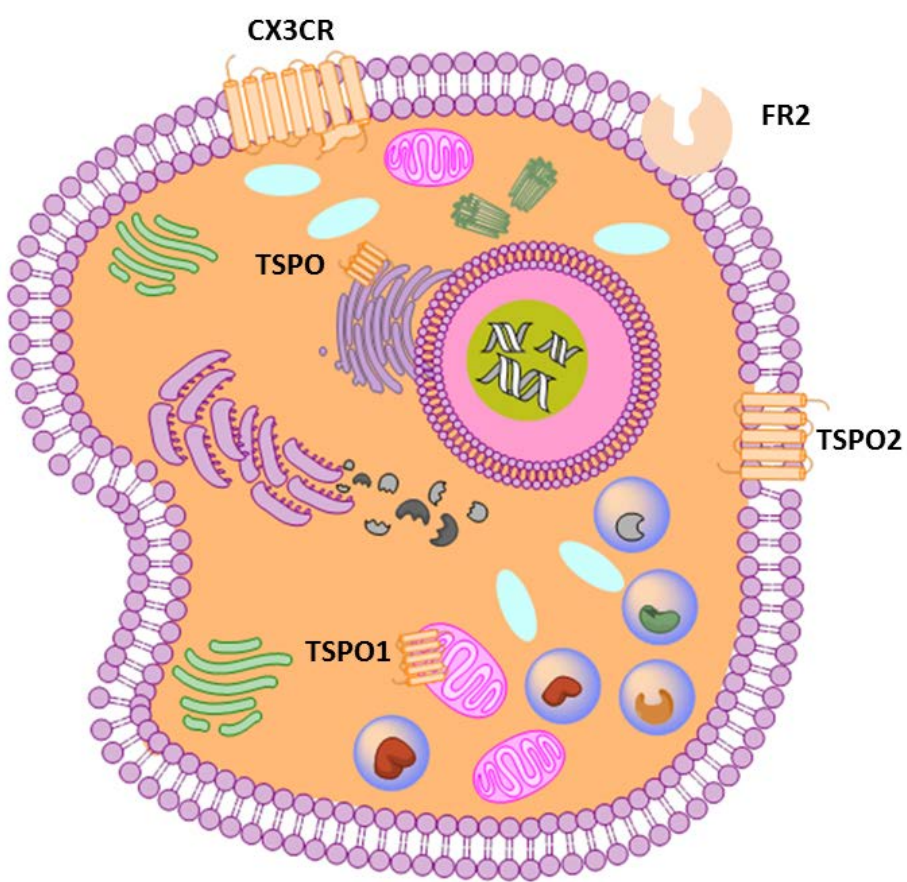

Mitochondrial TSPO1: $18 \mathrm{kDa}$ translocator protein with five-transmembrane-domain structure (5TM) [66] [67] involved in transport of cholesterol, porphyrine, proteins and ions and closely related to several proteins belonging to the mitochondrial permeability transition pore (mPTP) [34] [35]. TSPO2: 5TM structure without binding site for isoquinoline; increasingly expressed on plasma membrane during differentiation of erythrocytes, which influences porphyrine transport in erythrocytes infected with plasmodium falciparum [66]. Microglial CX3CR: $G_{i}$ protein-coupled receptor [50] involved in developmental pruning and adult hippocampal neurogenesis [142] [143] Folate receptor FR2: GPI anchored globular receptor [57] [58] responsible for capture and internalization of folic acid; potentially specific for M2 subtype of microglia [30].

Figure 1. Subcellular localization of the isoforms of the $18 \mathrm{kDa}$ translocator protein (TSPO), of the chemokine receptor CX3CR and of the folate receptor FR2.

The target TSPO1 is a protein of the outer mitochondrial membrane [31] [32], more precisely, it is located at the contact sites between the outer and inner membrane [33]. Functional tasks of TSPO1 have been presumed in porphyrine transport, protein import, cholesterol transport, steroid biosynthesis, ion transport, cell proliferation and differentiation [34] [35] [36]. TSPO is found, especially, in cells with steroid synthesis. The evolutionary conserved protein is constituent of species from bacteria to mammals upstairs [37]. A $3 \mathrm{D}$-crystal structure of bacterial as well as of mammalian TSPO has been published, recently [33] [38] [39] [40]. The mitochondrial protein TSPO1 is closely associated with the voltage-dependent anion channel (VDAC) and further parts of the mitochondrial permeability transition pore (mPTP) involved in apoptotic and anti-apoptotic processes [31] [32] [41] [42] [43].

Potency as biomarkers of microglia and imaging targets promise also the integrins CD18 and CD68 [37] [44], the chemokine receptor CX3CR1 [45] [46] [47], and the folate receptor subtype FR2 [48]. The latter two membrane receptors and their expression in the brain gained rising attention by the PET community during the last decade. 
CX3CR1 (Fractalkine receptor) is a $\mathrm{G}_{\mathrm{i}}$ protein-coupled receptor able to interact with fractalkines (FKN, neurotactin) [45] [49], its endogenous polypeptide ligand (373 a.a.r.) produced predominantly in endothelial cells and neurons, in CNS, kidney, lungs, heart, liver, intestines and placenta [46]. CX3CR1 has been observed in neurons and microglia. Its expression in activated microglial cells can be enhanced 10fold [46] [47].

Proposals initiating synthesis of first small molecule CX3CR1 ligands came predominantly from high throughput screening experiments and revealed, especially, thio-thiazolo pyrimidine derivatives as potential lead structures for imaging agents [50] [51] [52]. For structural studies is employed, currently, the chemokine receptor homolog US28 with 38\% homologies to CX3CR1 [53].

Folate receptors attracted originally attention because of their overexpression in tumors and as a potential cargo receptor for the transport of cytostatic drugs and antimetabolites for therapeutic purposes. FR1 has been observed also in epithelial cells of the choroid plexus but FR2 folate receptor $(=\mathrm{F} \beta$ folate receptor) [54]-[59] has been shown to be overexpressed in activated microglia,especially, in the anti-inflammatory M2 cells. The site specific presence of M2 cells in rheumatoid arthritis and inflammatory processes in cardiovascular diseases suggests diagnostic potential of folate receptor ligands [54] [55] [59].

The present study regards the current availability of small-molecule TSPO1 ligands, their clinical advantages and disadvantages as well as the present experiences with CX3CR1 ligands and FR2 substrates as potential PET tracers for brain imaging.

\section{TSPO as PET Target}

Already, during the 70 ties and 80 ties of the last century was recognized the 18 $\mathrm{kDa}$ translocator protein (TSPO; originally classified as peripheral benzodiazepine receptor $=\mathrm{PBR}$ ) [32] is not restricted to peripheral organs, but also present in CNS, glial and ependymal cells. Although the densities of TSPO in the brain is a magnitude below that in kidney, heart, testis, ovary and uterus its increased expression in pathophysiological conditions like multiple sclerosis (MS), amyotrophic lateral sclerosis (ALS) and Alzheimer's disease (AD) suggested a suitability as a biomarker of early stages of pathogenesis in inflammatory diseases or inflammation-related disorders [60] [61].

In subcellular fractions of brain extracts, the mitochondrial localization of TSPO1 was revealed [62] [63] [64] [65]. Later reports described a TSPO2 isoform in the plasma membrane during differentiation of erythrocytes [66].

TSPO2 has been presumed also in nuclear membranes or close to nuclear membranes and in endoplasmic reticulum [35]. In contrast to TSPO1, it lacks in birds and mammals the isoquinoline-binding site [42].

For evaluation of potential structure-activity-relationships (SAR) of TSPO1, close relations can be important with further mitochondrial proteins involved in energy production and mitochondrial homeostasis as part of the mPTP complex 
[31] [32] [67] [68] [69] or of the recently introduced transduceosom [70] [71]. Even if the role of mPTP is in part controversial [67] and not completely understood, it is presumed to be a key structure in several pathophysiological processes related to reperfusion injury, amyotrophic lateral sclerosis, Alzheimer's disease, alteration following traumatic injury and myopathies [67] [68]. Currently, the first reports on the 3D structure of TSPO1 [40] promise also new insight on the oligomeric structures of the protein and potential relationships to other structures of the mitochondrial membrane.

Some TSPO ligands are supposed to bind rather to the multi protein complex than to single sub-proteins forming it.

An interesting contribution to understanding of subcellular compartmentation of TSPO has been provided, recently, by Yasin et al. [72] with investigations in U118MG glioma cells. The first generation-TSPO ligand PK11195 is known to interact with TSPO1 by opening of the transition pore. The authors [72] demonstrated PK11195 prompts the cell to dislocate the binding places of the ligand from localizations widely spread within the cell (i.e. to mitochondria) to such located close to the nucleus [72]. This suggests a role of TSPO also in the promotion of interactions between mitochondria and nucleus by an influence on subcellular compartmentation of mitochondria.

A special challenge for imaging with small molecule TSPO ligands was the identification of high affinity binders (HABs), low affinity binders (LABs) and mixed affinity binders (MABs) among the participants of clinical studies, due to presence of a rs6971 polymorphism [73] [74] [75] causing the exchange or partial exchange of Ala147 by threonine. The percentage of LABs among the study participant has been reported between $9 \%$ and 30\% [74] [75] and can influence imaging results by different extent also depending from the structure of the ligand applied.

\subsection{TSPO-Ligands}

\subsubsection{First Generation}

\section{1) Benzodiazepine compounds}

An early work by Basile and Skolnick [27] using the diazepam derivative Ro5-4864 [Figure 2, (2)] and the benzodiazepine antagonist flumazenil (Ro15-1788) [Figure 2, (4)]), revealed different binding patterns of the two ligands for various subcellular fractions (For Ro-4864: $1.132 \mathrm{fmol} / \mathrm{mg}$ protein in mitochondria; $302 \mathrm{fmol} / \mathrm{mg}$ protein in synaptosomes and for Ro15-1788: 1.136 $\mathrm{fmol} / \mathrm{mg}$ protein in synaptosomes; $583 \mathrm{fmol}$ protein/mg in mitochondria). Meanwhile, it is well known, by far, not only benzodiazepines can bind at the former peripheral "benzodiazepine" receptor (PBR) and the 5TM-protein is distinct from the CBR (central benzodiazepine receptor) corresponding to the $\mathrm{GABA}_{\mathrm{A}}$ receptor in some structural features [26] [77] [78] [79]. Awad \& Gavish described only few years later Ro5-4864 as a rather inappropriate PET tracer. This was, especially, due to a high non-specific binding of $90 \%$ of total in 
<smiles>O=C1CN=C(c2ccccc2Cl)c2cc([N+](=O)[O-])ccc2N1</smiles><smiles>CN1C(=O)CN=C(c2ccccc2)c2cc(Cl)ccc21</smiles>

2<smiles>CN1C(=O)CN=C(c2ccc(Cl)cc2)c2cc(Cl)ccc21</smiles><smiles>CCOC(=O)c1ncn2c1CN(C)C(=O)c1cc(F)ccc1-2</smiles><smiles></smiles><smiles>CCC(C)N(C)C(=O)c1cc2ccccc2c(-c2ccccc2Cl)n1</smiles>

8<smiles>CCC(C)N(C)C(=O)c1cc2ccccc2nc1-c1c(F)ccc([N+](=O)[O-])c1F</smiles>

9

1 5-(2-chlorophenyl)-7-nitro-1,3-dihydro-2H-benzo[e][1,4]diazepin-2-one; 2 7-chloro-1-methyl5-phenyl-1,3-dihydro-2H-benzo[e][1,4]diazepin-2-one; 3 7-chloro-5-(4-chlorophenyl)-1-methyl1,3-dihydro-2H-benzo[e][1,4]diazepin-2-one; 4 Ethyl 8-fluoro-5-methyl-6-oxo-5,6-dihydro-4Hbenzo[f]imidazo[1,5-a][1,4]diazepine-3-carboxylate; 5 6-(4-methoxyphenyl) benzo[b]pyrrolo[1,2-d][1,4] thiazepin-8-yl acetate; 6 6-phenyl-benzo[b]pyrrolo[1,2-d][1,4]oxazepin-8-yl diethylcarbamate; $7 \mathrm{~N}$ ((R)-sec-butyl)-3-ethyl-4-(2-fluorophenyl)-N-(methyl- $\left.{ }^{11} \mathrm{C}\right)$ quinoline-2-carboxamide; $8 \mathrm{~N}$-(sec-butyl)1-(2-chlorophenyl)-N-(methyl- $\left.{ }^{11} \mathrm{C}\right)$ isoquinoline-3-carboxamide; $9 \mathrm{~N}$-(sec-butyl)-1-(2-(fluoro- $\left.{ }^{18} \mathrm{~F}\right)-5$ nitrophenyl)-N-methylisoquinoline-3-carboxamide; ChemDraw (http://www.cambridgesoft.com/) was used for verification of IUPAC names.

Figure 2. First generation TSPO ligands.

membranes of human cerebral cortex. They, observed with PK11195 lower $\mathrm{B}_{\max }$ values (255 $\pm 23 \mathrm{fmoles} / \mathrm{mg}$ protein), but the potency of displacement of $\left[{ }^{3} \mathrm{H}\right] \mathrm{PK} 11195$ was with unlabelled PK11195 two orders of magnitude higher than with unlabelled Ro5-4864 [78]. The change from benzodiazepine lead structure to isoquinoline and quinoline promised markedly higher specificities.

\section{2) Non-benzodiazepine, first generation ligands}

The isoquinoline R-PK11195 [Figure 2; (8)] was the first non-benzodiazepine ligand of TSPO1 introduced in PET. The enantiomeric active form of the molecule is now the most frequently used TSPO PET tracer [1]. A multitude of investigations has been published with patients suffering from Parkinson's disease, Huntington's disease, multiple sclerosis, Alzheimer's disease and dementia [1] 
[80] [81]. However, yet relatively high non-specific binding and low signal-to-noise ratio, as well as high plasma protein binding and low brain permeability have been described as drawbacks also for the in vivo observations with the compound [73] [74].

PK14105 [Figure 2, (9)], a structurally similar candidate suitable as ${ }^{18} \mathrm{~F}$-labelled tracer with promising properties, was early ranged in minor position, especially, because of somewhat weaker binding affinity [82] [83].

In spite of drawbacks in specificity, clinical investigations with $\left[{ }^{11} \mathrm{C}\right] \mathrm{PK} 11195$ revealed some interesting items on inflammatory processes in brain diseases.

Zhang [73] reviewed investigations using $\left[{ }^{11} \mathrm{C}\right] \mathrm{PK} 11195$ in frontotemporal dementia which is a neurodegenerative disease of people $<65$ years of age. The observations suggested accumulation in brain regions contralateral to the atrophic site of the brain and indicated early activations of microglia with potency to start neurodegenerative processes. Zhang [73] regarded the early activation of microglia, far from the later place of tissue degeneration, as signal of processes preceding the well-known degenerative alteration on the end stage of the diseases. An early detection might open a window for preventive treatment with the aim of delay or suppression of severe consequences of diseases.

Scott et al. [84] demonstrated maintenance of thalamic inflammation even 17 years after traumatic brain injury. Inflammation was observed also at a place far from the original traumatic injury and along axonal connections between initially injured area and late inflammatory processes. The role of connectivity and impairment of axonal structures and functions becomes now an issue of neuro research questioning.

\subsubsection{Second Generation Compounds}

The small molecule TSPO ligands of the second generation, like FEPPA, FEMPA and DPA-714, AC5216 [Figure 3, (14)-(17)], DAA1106, FEDAA1106 [Figure 3, ((10), (11))], PBR111, vinpocetine or PBR06 and PBR28 [Figure 3; ((12), (13))] show lower non-specific binding than the first generation compounds [34] [35] [83] [84] [85] [86].

Many of the second generation structures comprise three separate ring systems which promise differences in binding behavior in comparison to the first generation structures by innate conformational conditions in contrast to first generation structures. First studies with the crystal structure of TSPO included the first generation compound PK11195 [33] [39] as well as the second generation compound DAA1106 [40] and proposed for both substances the same binding site as for porphyrine. That supports rather the presumption that the change in the basic scaffold of the ring systems was less important for the binding properties of the compounds than the kind of substituents.

Some compounds, like FEDAA1106 and PBR06, form metabolites which can be a problem for the correct detection of microglial activation [73] [87].

Moreover, the inter-subject variations of these ligands are higher than for the first generation [72]. Responsible for these variations can be the rs6971 poly- 
<smiles>COc1ccc(OC)c(CN(C(C)=O)c2cc([18F])ccc2Oc2ccccc2)c1</smiles>

10<smiles>CCN(CC)C(=O)Cc1c(C2=CCC(OCCC(F)F)C=C2)nn2c(C)cc(-c3ccc(C)cc3)nc12</smiles>

16<smiles>CC=CCC(=O)Oc1ccccc1CN(C(C)=O)c1cnccc1Oc1ccccc1</smiles>

13<smiles>COc1ccc(OCF)c(CN(C(C)=O)c2cccnc2Oc2ccc(O)cc2)c1</smiles><smiles>CCN(Cc1ccccc1)C(=O)Cn1c(=O)n([14CH3])c2cnc(-c3ccccc3)nc21</smiles>

17

$10 \mathrm{~N}$-(2,5-dimethoxybenzyl)-N-(5-(fluoro- $\left.{ }^{-18} \mathrm{~F}\right)$-2-phenoxyphenyl)acetamide; $11 \mathrm{~N}$-(5-fluoro-2-phenoxyphenyl)-N-(5-(2-(fluoro- $\left.{ }^{18} \mathrm{~F}\right)$ ethoxy)-2-methoxybenzyl)acetamide; $12 \mathrm{~N}-\left(2\right.$-(methoxy- $\left.{ }^{11} \mathrm{C}\right)$ benzyl)$\mathrm{N}$-(4-phenoxypyridin-3-yl)acetamide; $13 \mathrm{~N}-\left(2-\left(\left(\right.\right.\right.$ fluoro $\left.-{ }^{18} \mathrm{~F}\right)$ methoxy $)$ benzyl)-N-(4-phenoxypyridin3-yl)acetamide; $14 \mathrm{~N}$-(2-(2-(fluoro- $\left.{ }^{18} \mathrm{~F}\right)$ ethoxy)benzyl)-N-(4-phenoxypyridin-3-yl)acetamide; $15 \mathrm{~N}$ (2-(2-fluoroethoxy)-5-methoxybenzyl)-N-(2-(4-methoxyphenoxy)pyridin-3-yl)acetamide; $16 \mathrm{~N}, \mathrm{~N}$ diethyl-2-(2-(4-(2-(fluoro- $\left.{ }^{18} \mathrm{~F}\right)$ ethoxy)cyclohexa-1,5-dien-1-yl)-7-methyl-5-(p-tolyl)pyrazolo[1,5a]pyrimidin-3-yl)acetamide; 17 N-benzyl-N-ethyl-2-(7-(methyl- $\left.{ }^{11} \mathrm{C}\right)-8$-oxo-2-phenyl-7,8-dihydro-9Hpurin-9-yl)acetamide.

Figure 3. Second generation TSPO ligands.

morphism resulting in three functional classes of participants (HABs, LABs, MABs) during clinical studies [73] [74] [87].

These observations are a challenge to genotypic selection of patients for respective diagnostic imaging probes. Additionally, prerequisites for the use of 
reference tissue methods had to be developed for second generation tracers. Functional consequences of polymorphisms can make it necessary to develop tissue reference methods for each condition i.e. high affinity binders or mixed affinity binders.

Furthermore, many second generation TSPO ligands bind not only to grey matter but to vascular tissues, too. Avoidance of complicate pharmacokinetic approaches as well as shortening of the general acquisition time would contribute to a better clinical feasibility of the method.

Currently, blood sampling necessary for creation of the input function for kinetic analysis; radioactivity time-activity curve (TAC) and plasma radioactivity curve and, especially, the necessity of arterial sampling complicates clinical investigations. For the example of TSPO-labelling with $\left[{ }^{18} \mathrm{~F}\right] \mathrm{FEPPA}$ in $\mathrm{AD}$ patient, Mabrouk et al. [88] estimated that, to date, no reference region with negligible binding has been identified in the brain. Similar problems are reported for other ligands of the second generation [87].

Suridjan et al. published [89] [90] an investigation in $21 \mathrm{AD}$ patients and 21 control participants (47 - 82 years of age) with the second generation TSPO1 ligand $\left[{ }^{18} \mathrm{~F}\right]$ FEPPA [Figure 3, (14)]. They found the $\left[{ }^{18} \mathrm{~F}\right] \mathrm{FEPPA}$ accumulation in $\mathrm{AD}$ patients with a two-compartment model significantly higher in grey matter than in white matter. The HABS identified genotypically showed higher binding than MABs in all ROIs [90].

Mabrouk et al. [88] and Koshimori et al. [91] could identify trends of different $\left[{ }^{18} \mathrm{~F}\right] \mathrm{FEPPA}$ binding in HABs and MABs among PD patients. However, these trends could not be confirmed after corrections for the partial volume effect [92].

Higher $\left[{ }^{18} \mathrm{~F}\right] \mathrm{FEPPA}$ binding in HAB-PD and MAB-PD patients compared to controls remained [88].

Varrone et al. reported [87] a clinical evaluation of $\left[{ }^{18} \mathrm{~F}\right]$ FEDAA11106 [Figure 3 , (11)] in seven $\mathrm{AD}$ patients (68 \pm 3 years of age) and eight controls (69 \pm 4 years) using, similar to Mabrouk's approach, a two-compartment model and Logan's analysis.

Possibly, the low size of the groups allowed no further evaluation and differentiation of HAB, MAB and LAB participants. The authors classified $\left[{ }^{18} \mathrm{~F}\right]$ FEDAA1106 as an inappropriate in vivo measure of microglia activation in the early course of AD. However, results of MMSE (Mini-Mental-State-Examination) corresponding only to mild cognitive impairment were not very different between the groups investigated by Varrone et al. (MMSE: $29 \pm 1$ in controls and $25 \pm 3$ in AD patients) [88] whereas in the reports by Suridjan [89] [90] and Mabrouk [88] were included also people with severe cognitive impairment.

In postmortem tissue of frontal cortex of AD patients and controls, Venneti et al. [93] demonstrated a good correlation between CD68 as immune-histological marker of activated microglia and microglial labelling with $\left[{ }^{3} \mathrm{H}\right] \mathrm{DAA} 1106$ [Figure 3, (11)] (Spearman's correlation coefficient r: 0.8904; $p<0.0002$ ) and with $\left[{ }^{3} \mathrm{H}\right] \mathrm{PK} 11195$ [Figure 2, (8)] (r: 0.7933, $\left.p<0.0062\right)$. 
Also in transgenic mice models (e.g. six month old 5XFAD mice vs. wild type) could be demonstrated in vivo with the second-generation tracer $\left[{ }^{11} \mathrm{C}\right] \mathrm{PBR} 28$ [Figure 3, (12)] a marked enhancement of TSPO labelling [94]. Moreover, Mirzaei et al. [94] described a good coincidence of binding of [ ${ }^{3} \mathrm{H}$ ]PBR28 [Figure 3, (12)] in 5XFAD animals with the localization of TSPO demonstrated immunochemically (Iba1).

\subsubsection{Third Generation Compounds and Recent Developments}

Wadsworth et al. [95] and Chau et al. [96] investigated three further classes of compounds for their suitability as PET tracers of TSPO: diaryl anilides, tetracyclic and tricyclic scaffolds. As a first candidate compound among the tricyclic structures, was investigated GE-180 [Figure 4 ((18), (19))] [36] [96].

With this compound started a generation of non-azepine tri and tetracyclic compounds of TSPO ligands.

GE-180 was subjected to first clinical safety tests in healthy volunteers, recently [36] [97]. The racemate was analysed for the functional roles of its enantiomers, kinetics of uptake, elimination as well as metabolization [97]. The enantiomer S-GE-180 [Figure 4, (19)] was shown to be the pharmacodynamically most suitable structure in the tricyclic carbazole class, with good metabolic stability in comparison to its R-enantiomer. With a $\log \mathrm{D}$ of 2.95 at $\mathrm{pH} 7.4$ the substance showed an appropriate lipophilicity in preclinical investigations. The authors recommended a reversible two-tissue-compartment model for the imaging of TSPO. A study using a one-compartment model as well as two-compartment models for this tracer in healthy volunteers was published in the same year by Feeney et al. [97]. Feeney et al. [97] used the cortical grey matter as pseudo-reference region based on observations by Owen et al. [98]. The latter described a negligible binding of $\left[{ }^{11} \mathrm{C}\right] \mathrm{PBR} 28$ in this region using the Lassen plot method with the purine derivative emapunil/XBD173 as TSPO inhibitor [99]. The results of these tests showed a relatively low uptake of $\left[{ }^{18} \mathrm{~F}\right] \mathrm{GE}-180$ into the brain which could not be explained by the structure of the compound or its physicochemical properties, finally. The authors [97] discussed a possible role of Pgp or other multidrug resistance proteins. Further information on phase I, II and III metabolism are not available at the moment. Differences between rs6971 genotypes in the investigated group of healthy volunteers were not observed. The authors remarked such differences might gain importance for investigations in diseased subjects. Finally, $\left[{ }^{18} \mathrm{~F}\right] \mathrm{GE}-180$ remains a candidate imaging tracer.

Already 2004, Okubo et al. (Taisho Pharmaceuticals Co) [100] reported on structure-activity investigations in tetracyclic compounds derived from the scaffold of FGIN-1-27.

Two series of compounds were compared for their affinities to PBR/TSPO1 $\left(\mathrm{IC}_{50}\right.$ in mitochondrial preparation of rat cerebral cortex).

First series were thiochromenoindoles with two favorite compounds (12e and 12f) [Figure 4, ((20), (21))] showing $\mathrm{IC}_{50}$ (with PK11195) of $0.44 \mathrm{nM}$ and 0.37 $\mathrm{nM}$. The other series were benzoimidazo-isoquinolines with $42 \mathrm{nM}$ (cmpd. 34a) 


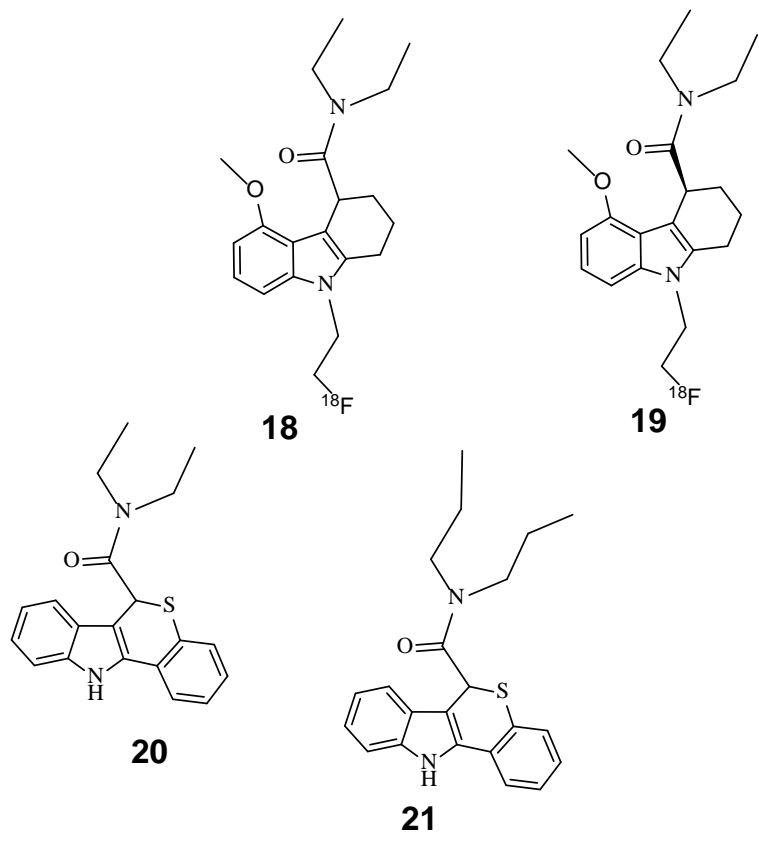

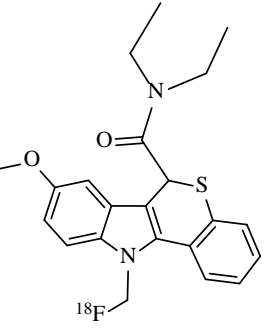

23

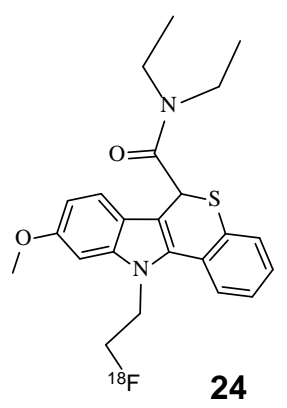

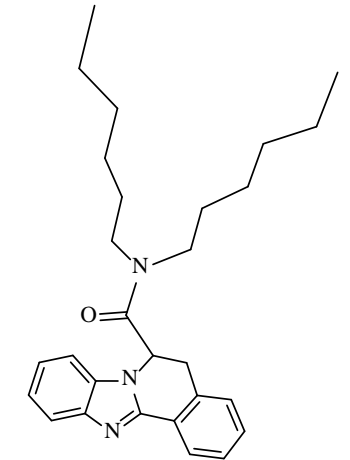

22

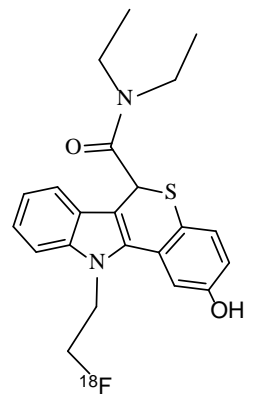

25

18 N,N-diethyl-9-(2-(fluoro- ${ }^{18} \mathrm{~F}$ )ethyl)-5-methoxy-2,3,4,9-tetrahydro-1H-carbazole-4-carboxamide; 19 (S)-N,N-diethyl-9-(2-(fluoro- ${ }^{18}$ F)ethyl)-5-methoxy-2,3,4,9-tetrahydro-1H-carbazole-4-carboxamide; 20 N,N-diethyl-6,11-dihydrothiochromeno[4,3-b]indole-6-carboxamide; 21 N,N-dipropyl-6,11dihydrothiochromeno[4,3-b]indole-6-carboxamide; $22 \mathrm{~N}, \mathrm{~N}$-dihexyl-5,6-dihydrobenzo[4,5]imidazo [2,1-a]isoquinoline-6-carboxamide; $23 \mathrm{~N}, \mathrm{~N}$-diethyl-11-((fluoro- $\left.{ }^{-18} \mathrm{~F}\right)$ methyl)-8-methoxy-6,11-dihydrothiochromeno[4,3-b]indole-6-carboxamide; 24 N,N-diethyl-11-(2-(fluoro- $\left.{ }^{18} \mathrm{~F}\right)$ ethyl)-9-methoxy-6,11dihydrothiochromeno[4,3-b]indole-6-carboxamide; 25 N,N-diethyl-11-(2-(fluoro- $\left.{ }^{18} \mathrm{~F}\right)$-ethyl)-2hydroxy-6,11-dihydrothiochromeno[4,3-b]indole-6-carboxamide.

Figure 4. Third generation of TSPO ligands and tetracyclines.

[Figure 4, (22)] and $74 \mathrm{nM}$ (compound 34c) as the best IC $_{50}$ achieved with PK11195. The benzoimidazoles, originally developed to reduce the lipophilicity of the potential tracers, showed, however, lower affinities and higher lipophilicity than the favored compounds of the first series [100].

O'Shea et al. (GE-Healthcare) [101] presented in 2013 some further structures derived from the pharmacophores of the thiochromenoindol series revealed, originally, by Okubo et al. with appropriate affinities but high lipophilicities [Figure 4, ((23), (24))].

A novel structural variation, different from the third generation scaffolds, was 
introduced by Fancelli et al. [68] with several series of derivatives of cinnamic acid and analogues of cyclosporine A, known as inhibitor of cyclophilin D. The compounds were designed by modification of the cinnamic phenyl ring, the aniline ring and the central linker of the cinnamic anilido scaffold [68]. Among these, the authors favored (E)-3-(4-fluoro-3-hydroxyphenyl)-N-naphthalen-1yl-acrylamide [Figure 5, (26)].

A potential breakthrough related to the limitations due to genotypic differences in TSPO1 was announced with the first in vitro data published by Ikawa et al. [102] about a new analogue of the first-generation TSPO ligand PK11195. For the synthesis of $\left[{ }^{11} \mathrm{C}\right]$ ER176 [Figure 5, (27)], the isoquinoline moiety of the parents compound was changed into a quinazoline moiety. The comparison of the affinity ratios of $\mathrm{HAB}$ versus LAB genotypes resulted for $\left[{ }^{11} \mathrm{C}\right.$ ]ER176 [Figure 5; (27)], PK11195 [Figure 2; (8)] and PBR28 in human tissues in vitro in ratios of $1.3: 1 ; 0.9: 1$ and 55:1, respectively, [102] indicating a low value of the new substance in comparison to the second generation tracer.

Ikawa et al. [102] reported that with the measurements with ER176, similarly like also for other tracers, differences in binding affinities related to genotypic subtypes were not revealed in control groups. One reason for the absence of differences could be the small size of the groups investigated. Another reason could be that the differences become visible only during the pathophysiological processes. In this case, PET would be able to supply a positive marker of inflammatory processes but cannot exclude it in case of negative result of labelling.

Briefly, all generations of TSPO ligands provided also representatives with appropriate binding affinities to the mitochondrial target protein. While the first generation radiotracers showed, especially, in the group of azepines yet high non-specific binding and limited selectivity, these drawbacks were reduced in the second generation TSPO ligands. However, genetic polymorphism became in vivo and clinically important and resulted in increasing inter-subject differences of PET-measurements.

Whether third generation tri and tetracyclic compounds meet the expectation on reduction of variations by genetic polymorphisms has to be finally elucidated.

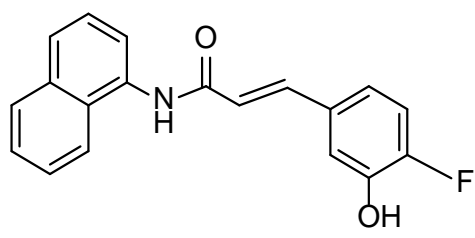

26

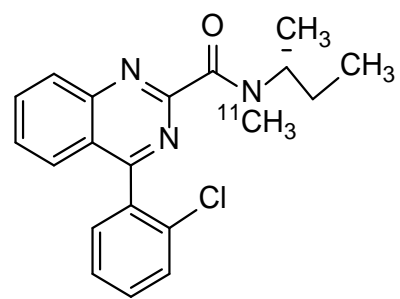

27

26 (E)-3-(4-fluoro-3-hydroxyphenyl)-N-(naphthalen-1-yl)acrylamide; 27 (R)-N-(sec-butyl)-4-(2chlorophenyl)-N-(methyl- $\left.{ }^{11} \mathrm{C}\right)$ quinazoline-2-carboxamide.

Figure 5. New TSPO ligands. 


\section{Plasma Membrane Targets}

\subsection{CX3CR1 Chemokine Receptor}

Most chemokine receptors are attributed to the G protein-coupled receptors (GPCR) while a few are atypical chemokine receptors (AKRs) which are not interacting with G-proteins [51] [103] [104].

CX3CR, potentially useful in diagnostics, belongs to a minor family among four subfamilies of GPC-chemokine receptors [53] [103] [104] [105] [106] characterized by the position of cysteines in the $\mathrm{N}$-termini of their endogenous ligands. In the CX3R ligand fractalkine (FKN), two cysteines are separated by three other a.a.r.s. in the $\mathrm{N}$-terminus.

CX3CR is highly expressed in the plasma membrane of activated microglial cells [107] [108] [109]. CXR3R1 (GPCR 13) has been found in spleen, brain (neurons and microglia) and subpopulations of leukocytes i.e. monocytes, macrophages, as well as osteoclasts, dendritic cells, neutrophils. Moreover, lymphocyte populations like T-cells are known to express CX3CR [105] [109] [110].

A high increase in expression of CX3CR [103] and high increase of CX3CR mRNA has been demonstrated in models of neuronal injury [110]. Like other chemokine receptors, CX3CR regulates trafficking of leukocytes to places of inflammatory reactions in the tissue [103] [104] [105].

In difference to other chemokine receptors and TSPO, is known only one endogenous CX3CR1 ligand.

The CX3CR ligand FKN is a 373 a.a.r. membrane-bound polypeptide [49], which is anchored in the cell membrane and supports the scavenging of leukocytes. The extracellular domain can be separated by tumor necrosis factor $\alpha$ converting enzyme (TACE) and is then present as a globular, extracellular polypeptide. By this way FKN is supposed to act as signaling peptide with inflammatory and homeostatic action as well.

The search for potential small molecule ligands of CX3CR1 has been realized by docking studies in homology models using the cytomegalovirus-encoded chemokine receptor homolog US28 [50], however, to date with limited success.

Maciejewski-Lenoir et al. [111] demonstrated in rat cell cultures expression/ release of FKN by astrocytes and neurons but not by microglia cells.

The role of $\mathrm{CX} 3 \mathrm{C}$ receptors in microglia is not completely clear, today, although it, without doubt, plays a role in the diapedesis of cells. The information about a toxic or protective role are similar ambivalent like for microglial cells [110].

Steen et al. [112] made the promiscuity of chemokine receptors for several peptide ligands responsible for the difficulties to develop effective small-molecule therapeutics targeting chemokine receptors. With regard to only one endogenous ligand, the CX3CR1 receptor provides better prerequisites than the most other chemokine receptors.

\subsection{Small Molecule Ligands of CX3CR1}

The use of microglial plasma membrane proteins as markers of activation or 
proliferation earns not only attention because it could be applied to patients which are PET-negative due to TSPO polymorphisms.

A well accessible marker protein of the plasma membrane could allow also kinetics and dynamics of potential ligands with better feasibility for imaging purposes than an intracellular target like TSPO1.

The small molecule ligands reported as potential PET tracers for CX3CR1, to date, are allosteric ligands with non-competitive displacement of FKN from the receptor.

Karlström et al. (Astra Zeneca) [109] published 2013 two series of thio-thiazolo pyrimidines and analysed the consequences of diverse substitutions of these lead structures. A first small molecule ligand, AZD8797 [Figure 6; (28)], was synthesized for the treatment of multiple sclerosis. The substance is an orally available CX3CR ligand. The $\mathrm{K}_{\mathrm{i}}$ (for the displacement of $\left[{ }^{125} \mathrm{I}\right]$ fractalkine) was $3.9 \pm 0.0$ $\mathrm{nM}$ and the selectivity compared to CXCR2 was 760fold. Malmquist et al. had published 2012 several methods for labelling of this compound with carbon-11 [113].

In 2015, Mease et al. [52] provided synthesis and first data of a ${ }^{18} \mathrm{~F}$-labelled PET tracer using AZD8797 as parent compound. FBTTP [Figure 6; (29)] is the fluorine-18 labelled AZD8797 derivative [52] with a $\mathrm{K}_{\mathrm{i}}$ of $23 \mathrm{nM}$ and 18 fold selectivity<smiles></smiles><smiles>CC(C)CC(CO)Nc1nc(SCc2ccccc2[18F])nc2nc(N)sc12</smiles>

29<smiles>CC(C)CC(CO)Nc1nc(SC(C)c2ccccc2)nc2[nH]c(=O)sc12</smiles>

30

28 2-((2-amino-5-((1-phenylethyl)thio)thiazolo[4,5-d]pyrimidin-7-yl)amino)-4-methyl-pentan-1-ol; 29 2-((2-amino-5-((2-fluoro-18F)benzyl)thio)thiazolo[4,5-d]pyrimidin-7-yl)amino)-4-methylpentan1-ol; 30 7-((1-hydroxy-4-methylpentan-2-yl)amino)-5-((2-phenylpropan-2-yl)thio)thiazolo[4,5-d] pyrimidin-2(3H)-one.

Figure 6. Potential CX3CR ligands. 
compared to CXCR2. Pomper et al. 2016 [114] described in patent application a series of further radio-fluorinated 7-amino-5-thio-thiazolo[4,5-d]pyrimidines as possible candidates for PET imaging.

The second series of CX3CR ligands revealed by Karlström et al. were thio thiazolo pyrimidine-2-ones [109]. The favored compound [Figure 6; (30)] showed a 80 fold selectivity in comparison with CXCR2 receptors at a $\mathrm{K}_{\mathrm{i}}$ (vs. $\left[{ }^{125} \mathrm{I}\right]$ fractalkine) of $5.8 \pm 0.4 \mathrm{nM}$.

Finally, there are several high-affinity small molecules with good selectivity to CX3CR1. The lipophilicity $>3.5$ could be an obstacle for the use of these substances as PET tracers. However, the compounds are regarded as potentially useful drugs in multiple sclerosis and provide lead structures for development of potential PET tracers with better pharmacokinetic properties.

\subsection{Folate Receptors}

Antifolates play a key role in therapies of cancer and rheumatic diseases since many decades. Folic acid is an essential part of the carbon-one metabolism. Because it is not synthesized in mammalian cells, it has to be obtained as Vitamin B9 dietary compound.

Four membrane proteins have been described to be involved into the uptake of folate [Figure 7, (31)] and of 5-methyltetrahydrofolate (5-MTHF) occurring in the liver after intestinal uptake of folic acid [115].

The proton-coupled folate transporter (PCFT) [116], highly expressed in small intestinum, is responsible for uptake of folate into the epithelium at low $\mathrm{pH}$. A low affinity carrier (reduced folate carrier; RFC: $\mathrm{K}_{d} 0.3-0.4 \mu \mathrm{mol} / \mathrm{l}$ for $5 \mathrm{MTHF}$ and $\mathrm{K}_{\mathrm{d}}$ $100-200 \mu \mathrm{mol} / \mathrm{l}$ for folic acid) has been described as a transmembrane protein with ubiquitary distribution [117] [118]. The channel is the preferred entry of folic acid in the normal cell [119]. The second folate uptake system comprises the folate receptors which are cysteine rich, glycosyl-phosphatidylinositol (GPI) anchored proteins with high affinity $\left(\mathrm{K}_{\mathrm{d}} 0.3 \mathrm{nM}\right)$ to folic acid and 5-MTHF. Four isoforms of the receptor (FR $\alpha=\mathrm{FR} 1 ; \mathrm{FR} \beta=\mathrm{FR} 2$; and $\mathrm{FR} \gamma=\mathrm{FR} 3$ and FR4) have been described [120], which should be of relevance when folic acid decreases to nanomolar concentrations in blood serum [118]. Homologies between the receptor isoforms are high with only small differences in the pharmacodynamically relevant structures. However, FR3 is a soluble receptor and, recently, a role of FR1 was described as a transcriptionally relevant protein, which may interact with nuclear structures following internalization [121] [122].

Blockage of the cerebral folate receptors and of the uptake across the blood brain barrier is known to cause marked folic acid deficiency in the brain [123] resulting in epileptic symptoms, which can be, potentially, reversed by folic acid application.

FR1, is localized in epithelial cells, kidney, lung and also in the choroid plexus. It is the most widely distributed subtype of the folate receptors. However, its 
<smiles>Nc1nc2ncc(CNc3ccc(C(=O)NC(CCC(=O)O)C(=O)O)cc3)nc2c(=O)[nH]1</smiles>

31<smiles>Nc1nc2ncc(CNc3ccc(C(=O)NC(CCC(=O)NNCc4ccc(F)cc4)C(=O)O)cc3)nc2c(=O)[nH]1</smiles>

32<smiles>CCCNC(=O)CC[C@H](NC(=O)c1ccc(NCc2cnc3nc(N)[nH]c(=O)c3n2)cc1)C(=O)O</smiles>

31 4-(((2-amino-4-oxo-3,4-dihydropteridin-6-yl)methyl)amino)benzoyl)-L-glutamic acid; 32 N2-(4(((2-amino-4-oxo-3,4-dihydropteridin-6-yl)methyl)amino)benzoyl)-N5-((4-(fluoro- $\left.{ }^{18} \mathrm{~F}\right)$ benzyl)amino)L-glutamine; 33 N2-(4-(((2-amino- 4-oxo-3,4-dihydropteridin-6-yl)methyl)amino)benzoyl)-N5-(4(4-(4-(fluoro- $\left.{ }^{18} \mathrm{~F}\right)$ butyl)-1H-1,2,3-triazol-1-yl)butyl)-L-glutamine.

Figure 7. Folate receptor ligands.

density is low, with exception of high expression in some tumors [117]. In general, folate receptor expression is typical for cells with functions in embryonic development [58].

FR2 is expressed in the cells of the hematopoetic system, in placenta, in spleen and thymus [117] [120] and has been mentioned as overexpressed with some specificity in anti-inflammatory macrophages/microglia [124] [125]. 
In consequence, folate receptors advanced to candidates for use in targeted therapy and imaging approaches, for instance, as a cargo system for folate conjugates with cytotoxic substances in the treatment of tumors [54] [55] [56] [57] [58] and to potential markers of glial activation in inflammatory diseases.

\subsection{Potential FR2 Ligands for PET Tomographic Imaging}

To date, most efforts for the development of ligands at FR2 receptors suitable for radio-imaging have been reported on SPECT tracers [126]. One report potentially interesting also for the analysis of cerebral microglia has been provided by Jager et al. [126] using [ $\left.{ }^{99 \mathrm{~m}} \mathrm{Tc}\right]$ folate for investigation of polarized macrophage subtypes in atherosclerotic plaques of cardiovascular patients [126], ex vivo. The authors identified, successfully, M1 and alternatively activated M2 macrophages with cytoflowmetric methods by detection of the M1 marker CD86, the M2 markers CD163 and FR2 receptors confirmed by polymerase chain reaction. The study could demonstrate high M2 levels in the plaques were consistent with high capacity for the uptake of [ $\left.{ }^{99 \mathrm{~m}} \mathrm{Tc}\right]$ folate. This observation should be of relevance also for the discrimination of M1 and M2 microglia in vivo and, potentially, in the brain.

FR2 enhancement is involved in the pathogenesis of arthritis but also of many other inflammatory diseases e.g. Crohn disease, diabetes, lupus erythematodes, glomerulonephritis [117] [127].

Overexpression of FR2 in the prefrontal cortex of rats was demonstrated, recently, in a model of acute and chronic stress [48] in parallel with other M2 microglial markers.

Brain uptake of folic acid, 5MTFH and methotrexate was first suggested by the results of a study by Spector and Lorenzo 1975 [128]. Since this time, it is known choroid plexus binds the major part of folic acid achieving its cells. Spector and Lorenzo [128] observed 5MTHF can also leave the cells of the choroid plexus in direction of the cerebrospinal fluid. Release of folate from FR1 protein is possible by interaction with the PCFT [129]. The key role of FR1 receptor became clear also from investigations on autoimmune diseases due to antibody blockade of FR1. FR ligands/substrates for PET are available, similar to SPECT tracers, predominantly, as diagnostics for tumors [55] [56] [130] where, however, especially the FR1 receptor plays a key role, while FR2 has been proposed rather as a target for imaging in arthritis and rheumatic diseases [54] [127].

Gent et al. [54] compared 2013 PET detection of subclinical synovitis using $\left[{ }^{18} \mathrm{~F}\right]$ fluoro-PEG-folate or the TSPO-first generation non-benzodiazepine PK11195 in KB cells (nasopharyngeal epidermal carcinoma cells) and in a rat model of mBSA induced arthritis [54]. Starting point of the study was the test of the novel PEG-folate tracer as potential label of FR2 overexpressed by macrophages during early stages of arthritis. The affinities of folic acid to FR1 and FR2 receptor are comparable $\left(\mathrm{K}_{\mathrm{d}} \sim 1 \mathrm{nM}\right)$ [54] [131] [132]. $\left[{ }^{18} \mathrm{~F}\right] \mathrm{PEG}$-folate showed in $\mathrm{KB}$ cell cul- 
ture an affinity to the folate receptor 1.8 fold lower than folic acid and 3 fold higher in comparison to 5MTHF [131] [132] [133] [134] [135].

The ex vivo analysis showed a better contrast for the detection of inflammatory regions with $\left[{ }^{18} \mathrm{~F}\right]$ fluoro-PEG-folate than with $\left[{ }^{11} \mathrm{C}\right] \mathrm{PK} 11195$, what the authors attributed to the faster clearance from blood and a lower periarticular uptake of the folate derivative in bones [54].

Synthesis of folate conjugates using diverse prosthetic groups was the method of choice, already years ago, because direct fluorination of folic acid was not possible.

Bettio et al. [130] synthesized a folate tracer using 4-fluorobenzylamine (FBA) as prosthetic group with region selective linkage to the $\alpha$-and to the $\gamma$-carbonyl group of folic acid [Figure 7, (31)]. Both compounds showed affinities comparable to that of folic acid at FRs expressed in KB31 cell cultures. Moreover, high resolution PET of mice bearing KB31 cell tumors in the shoulder region showed high accumulation of the folate-FBA-regioisomers in the tumors in difference to negligible accumulation of $\left[{ }^{18} \mathrm{~F}\right] \mathrm{FDG}$.

Ross et al. report in 2008 [132] similar results comparing $\alpha$ and $\gamma$ - $\left[{ }^{18} \mathrm{~F}\right] \mathrm{FBA}$ folate and $\left[{ }^{18} \mathrm{~F}\right]$-Click folate [Figure $\left.7,(32)\right]$ in $\mathrm{KB}$ cells and a rat model of $\mathrm{KB}$ tumor in vivo, where Click folate, however, showed no sufficient pharmacokinetic properties [136] with convincing improvements in comparison to the FBA-folates.

At least, there is no small molecule ligand, at the moment, binding to FR2 at a motif of the protein which allows selective distinction from FR1. The majority of available ligands are folate conjugates [59] with exception of 2-[ $\left.{ }^{18} \mathrm{~F}\right]$ fluorofolic acid [136] which is regarded with a $\mathrm{K}_{\mathrm{i}}$ of $1.8 \mathrm{nM}$ as a promising PET tracer for tumors. If folate-based tracer can be efficient also in monitoring microglial activation in the brain with intact blood brain barrier remains to be elucidated.

\section{Summary and Conclusions}

Visualization of microglial activities as a key factor in pathogenesis and progression of neurodegenerative diseases [1] [5] [8] [9] [14] [15] [16] [28] [137] is increasingly included in the development of new in vivo-strategies of brain imaging. The target preferred in clinical investigations remains, currently, the well-known mitochondrial TSPO1. But during the last decade also proteins of plasma membrane became potential binding sites for PET tracer.

Overexpression of TSPO in brain tissue subjected to inflammatory diseases has been confirmed by postmortem studies [93] as well as in animal experiments. Three generations of small molecule TSPO ligands have been proposed as PET tracers: 1) azepines and quinolones; 2) predominantly, compounds with three separate non-azepine and non-isoquinoline ring systems 3) tri- and tetracyclic compounds. The third generation of TSPO ligands was expected to reduce the inter-subject variations caused by the presence of three different binding types of study participants due to the rs6971 polymorphism. $\left[{ }^{18} \mathrm{~F}\right] \mathrm{GE}-180$ as the first of the 
third generation structures showed, generally, appropriate pharmacokinetic properties with exception of a low uptake into the brain. In first clinical tests with healthy volunteers, no differences between the binding types were observed. However, an influence of the various genotypes in patients is yet not excluded.

The broader clinical experience with second generation compounds suggests that the tracers among these with the best properties, like $\left[{ }^{18} \mathrm{~F}\right] \mathrm{FEPPA}$ or $\left[{ }^{11} \mathrm{C}\right] \mathrm{PBR} 28$ and its fluorinated analogue remain on the schedule of clinical trials [138] [139] [140].

New insights on protein-ligand interactions and protein-protein relationships in the mitochondrial membrane can be expected now also from molecular dynamics studies using the crystal structure of TSPO [38] [39] [40]. This should offer not only new information on the physiological and pathophysiological role of TSPO in inflammatory diseases but also on potential protective mechanisms in infectious diseases like malaria [66].

For the PET targets on the plasma membrane, CX3CR1 and FR2, polymorphisms of relevance for the imaging results, similar to that of second generation ligands of TSPO, are not known, currently.

CX3CR1 ligands proposed recently by Karlström et al. [109] showed appropriate binding affinities and selectivity. Their high lipophilicity was a tribute to their original purpose as an orally applicable therapeutic in multiple sclerosis. With regard to the application as a PET tracer it is rather a drawback. AZD8797 as well as related derivatives open a door for further modifications of potential lead structures.

Hitherto, small molecule ligands or folate conjugates binding to FR1 and FR2 specifically are not available. A PET labelling of folate receptors in inflammatory processes becomes specific for the FR2 subtype only by the distribution of the FR2-expressing M2 subtype of activated microglia.

On the other hand, distribution of FR1 and FR2 as well as their contributions to the cerebral uptake of folate through the epithelial cells of the choroid plexus and from the ventricular or spinal cerebrospinal fluid raise new questions also for potential imaging applications apart from tumor diseases. Additionally, the time course of such processes and their role in comparison to a direct transfer of folate, folate conjugates and analogues across the blood vessels would be an important item for the estimation of a potential diagnostic value of FR ligands in clinical PET imaging methods. Moreover, the recognition that the permeability of the blood brain barrier increases with rising age earns some attention [141].

\section{Acknowledgements}

This paper is dedicated to Pr. Peter Illes (Rudolf-Boehm-Institute of Pharmacology, University Leipzig) on the occasion of his $75^{\text {th }}$ birthday.

\section{References}

[1] Politis, M., Su, P. and Piccini, P. (2012) Imaging of Microglia in Patients with Neurodegenerative Disorders. Frontiers in Pharmacology, 3, Article 96. 
https://doi.org/10.3389/fphar.2012.00096

[2] Wei, J., Gambrusiewicz, K. and Heimberger, A. (2013) The Controversial Role of Microglia in Malignant Glioma. Clinical and Developmental Immunology, 2013, Article ID 285246. http://doi.org/10.1155/2013/285246

[3] Tremblay, M.-E. and Majewska, A.K. (2011) A Role for Microglia in Synaptic Plasticity. Communicative and Integrative Biology, 4, 220-222. https://doi.org/10.4161/cib.4.2.14506

[4] Bechade, C., Cantaud-Belarif, Y. and Bessis, A. (2013) Microglial Control of Neuronal Activity. Frontiers in Cellular Neuroscience, 7, Article 32. https://doi.org/10.3389/fncel.2013.00032

[5] Schafer, D.P., Lehrmann, E.K. and Stevens, B. (2013) The "Quad-Partite" Synapse: Microglia-Synapse Interactions in the Developing and Mature CNS. GLIA, 61, 24-36. https://doi.org/10.1002/glia.22389

[6] Neiva, I., Malva, J.O. and Valero, J. (2014) Can We Talk about Microglia without Neurons? A Discussion of Microglial Cell Autonomous Properties in Culture. Frontiers in Cellular Neuroscience, 8, Article 202. https://doi.org/10.3389/fncel.2014.00202

[7] Abud, E.M., Ramirez, R.N., Martinez, E.S., Healey, L.M., Nguyen, C.H.H., Newman, S.A., Yeromin, A.V., Scarfone, V.M., Marsh, E.M., Fimbres, C., Caraway, C.A., Fote, G.M., Madany, A.M., Agrawal, A., Kayed, R., Gylys, K.H., Cahalan, M.D., Cummings, G.M., Antel, J.P., Mortazavi, A., Carson, M.J., Poon, W.W. and Blurton-Jones, M. (2017) IPSC-Derived Human Microglia-Like Cells to Study Neurological Diseases. Neuron, 94, 278-293. https://doi.org/10.1016/j.neuron.2017.03.042

[8] Kettenmann, H., Hanisch, U.-K., Noda, M. and Verkhratskii, A. (2011) Physiology of Microglia. Physiological Reviews, 91, 461-553. https://doi.org/10.1152/physrev.00011.2010

[9] Dudvarski-Stankovic, N., Teodorczyk, M., Ploen, R., Zipp, F. and Schmidt, M.H.H. (2016) Microclia-Blood Vessel Interactions: A Double Edged Sword in Brain Pathology. Acta Neuropathologica, 131, 347-363. https://doi.org/10.1007/s00401-015-1524-y

[10] Rovida, E. and Sbarba, P.D. (2015) Colony-Stimulating Factor-1 Receptor in the Polarization of Macrophages: A Target for Turning Bad to Good Ones? Journal of Clinical and Cellular Immunology, 6, 379. https://doi.org/10.4172/2155-9899.1000379

[11] Jacobs, A.H. and Tavitian, B. (2012) Noninvasive Molecular Imaging of Neuroinflammation. Journal of Cerebral Blood Flow \& Metabolism, 32, 1393-1415 https://doi.org/10.1038/jcbfm.2012.53

[12] Jung, S., Alberti, J., Graemmel, P., Sunshine, M.J., Kreutzberg, G.W., Sher, A. and Littman, D.R. (2000) Analysis of Fractalkine Receptor CX3CR1 Function by Targeted Deletion and Green Fluorescent Protein Reporter Gene Insertion. Molecular \& Cellular Biology, 20, 4106-4114.

https://doi.org/10.1128/MCB.20.11.4106-4114.2000

[13] Davalos, D., Grutzendler, J., Yang, G., Kim, J.V., Zuo, Y., Jung, S., Littman, D.R., Dustion, M.L. and Gan, W.-B. (2005) ATP Mediates Rapid Microglial Response to Local Brain Injury In Vivo. Nature Neuroscience, 8, 752-758. https://doi.org/10.1038/nn1472

[14] Nimmerjahn, A., Kirchhoff, F. and Helmchen, F. (2005) Resting Microglial Cells are Highly Dynamic Surveillants of Brain Parenchyma In Vivo. Science, 308, 1314-1319 https://doi.org/10.1126/science.1110647 
[15] Gaikwad, S.M. and Heneka M.T. (2013) Studying M1 and M2 State in Adult Microglia. In: Joseph, B. and Venero, J.L., Eds., Microglia: Methods and Protocols, Methods in Molecular Biology, Vol. 1041, (C) Springer Science+Business Media, New York, 185-197. https://doi.org/10.1007/978-1-62703-520-0_18

[16] Burguillos, M.A. (2013) Use of Mesoscale Discovery to Examine Cytokine Content in Microglial Cell Supernatant. In: Joseph, B. and Venero, J.L., Eds., Microglia: Methods and Protocols, Methods in Molecular Biology, Vol. 1041, (C) Springer Science+Business Media, New York, 93-100. https://doi.org/10.1007/978-1-62703-520-0_11

[17] Mildner, A. (2017) Ghost in the Shell: Identification of Microglia in the Human Central Nervous System by P2Y12 Receptor. Neural Regeneration Research, 12, 570-571. https://doi.org/10.4103/1673-5374.205090

[18] Lawson, L.J., Perry, V.H., Dri, P. and Gordon, S. (1990) Heterogeneity in the Distribution and Morphology of Microglia in the Normal Adult Mouse Brain. Neuroscience, 39, 151-170. https://doi.org/10.1016/0306-4522(90) 90229-W

[19] Gehrmann, J., Matsumoto, Y. and Kreutzberg, G.W. (1995) Intrinsic Immuneffector Cell of the Brain. Brain Research Reviews, 20, 269-287. https://doi.org/10.1016/0165-0173(94) 00015-H

[20] Hambarzumyan, D., Gutmann, D.H. and Kettenmann H. (2016) The Role of Microglia and Macrophages in Glioma Maintenance and Progression. Nature Neuroscience, 19, 20-27. https://doi.org/10.1038/nn.4185

[21] Haenseler, W., Sansom, S.N., Buchrieser, J., Newey, S.E., Moore, C.S., Nicholls, F.J., Chintawar, S., Schnell, C., Antel, J.P., Allen, N.D., Cader, M.Z., Wade-Martins, R., James, W.S. and Coley, S.A. (2017) A Highly Efficient Human Pluripotent Stem Cell Microglia Model Displays a Neuronal Co-Culture Specific Expression Profile and Inflammatory Response. Stem Cell Reports, 8, 1727-1747. https://doi.org/10.1016/j.stemcr.2017.05.017

[22] Schulz, C., Gomez Perdiguero, E., Chorro, L., Szabo-Rogers, H., Cagnard, N., Kierdorf, K., Prinz, M., Wu, B., Jacobsen, S.E.W., Pollard, J.W., Frampton, J., Liu, K.J. and Geissmann, F. (2012) A Lineage of Myeloid Cells Independent of Myb and Hämatopoetic Stem Cells. Science, 336, 86-90. https://doi.org/10.1126/science.1219179

[23] Ginhoux, F. and Prinz, M. (2015) Origin of Microglia: Current Concepts and Past Controversies. Cold Spring Harbor Perspective in Biology, 7, a020537. https://doi.org/10.1101/cshperspect.a020537

[24] Eyo, U.B. and Wu, L.J. (2013) Bidirectional Microglia-Neuron Communication in the Healthy Brain. Neural Plasticity, 2013, Article 456857. https://doi.org/10.1155/2013/456857

[25] Gomes-Leal, W. (2013) Microglial Physiopathology: How to Explain the Dual Role of Microglia after Acute Neural Disorders? Brain and Behavior, 2, 345-356. https://doi.org/10.1002/brb3.51

[26] Boche, D., Perry, V.H. and Nicoll, A.R. (2013) Review: Activation Patterns of Microglia, and Their Identification in the Human Brain. Neuropathology and Applied Neurobiology, 39, 3-18. https://doi.org/10.1111/nan.12011

[27] Basile, A. and Skolnick, P. (1986) Subcellular Localization of "Peripheral-Type" Binding Sites for Benzodiazepines in Rat Brain. Journal of Neurochemistry, 46, 305-308. https://doi.org/10.1111/j.1471-4159.1986.tb12965.x

[28] Wohleb ES. (2016) Neuron Microglia Interactions in Mental Health Disorders: "For Better, and for Worse”. Frontiers in Immunology, 7, Article 544. 
https://doi.org/10.3389/fimmu.2016.00544

[29] Garcia, J.A., Cardona, S.M. and Cardona, A.E. (2013) Chapter 27: Analysis of Microglia Effector Function Using CX3CR1-GFP-Knock in Mice. In: Joseph, B. and Venero, J.L., Eds., Microglia: Methods and Protocols, Methods in Molecular Biology, Vol. 1041, (C) Springer Science+Business Media, New York, 307-317.

[30] Tronel, C., Largeau, B., Ribeiro, M.J.S., Guilloteau, D., Dupont, A.-C. and Arlicot, N. (2017) Molecular Targets for PET Imaging of Activated Microglia: The Current Situation and Future Expectations. International Journal of Molecular Sciences, 18, 802. https://doi.org/10.3390/ijms18040802

[31] Veenman, L., Alten, J., Linnemanstöns, K., Shandalov, Y., Zeno, S., Lakomek, M., Gavish, M. and Kugler, W. (2010) Potential Involvement of $\mathrm{F}_{0} \mathrm{~F}_{1}-\mathrm{ATP}$ (synth) ase and Reactive Oxygen Species in Apoptosis Induction by the Antineoplastic Agent Erucylphosphohomocholine in Glioblastoma Cell Lines: A Mechanism for Induction of Apoptosis via the $18 \mathrm{kDa}$ Mitochondrial Translocator Protein. Apoptosis, 15, 753-768. https://doi.org/10.1007/s10495-010-0460-5

[32] Krestinina, O.V. Grachev, D.E., Odinokova, D.E., Reiser, G., Evtodienlo, Yu.V. and Azarashvili, T.S. (2009) Effect of Peripheral Benzodiazepine Receptor (PBR/TSPO) Ligands on Opening of $\mathrm{Ca}^{2+}$-Induced Pore and Phosphorylation of 3.5-kDa Polypeptide in Rat Brain Mitochondria. Biochemistry (Moscow), 74, 421-429. https://doi.org/10.1134/S0006297909040105

[33] Jaremko, L., Jaremko, M., Giller, K., Becker, S. and Zweckstetter, M. (2014) Structure of the Mitochondrial Translocator Protein in Complex with a Diagnostic Ligand. Science, 343, 1363-1366. https://doi.org/10.1126/science.1248725

[34] Denora, N., Jacobazzi, R.M., Natile, G and Margiotta, N. (2017) Metal Complexes Targeting the Translocator Protein (18 kDa) (TSPO). Cooordination Chemistry Reviews, 341, 1-18. https://doi.org/10.1016/j.ccr.2017.03.023

[35] Rupprecht, R., Papadopoulos, V., Rammes, G., Baghai, T.C., Fan, J., Akula, N., Groyer, G., Adams, D. and Schumacher, M. (2010) Translocator Protein (18 kDa) (TSPO) as a Therapeutic Target for Neurological and Psychiatric Disorders. Nature Reviews Drug Discovery, 9, 971-988. https://doi.org/10.1038/nrd3295

[36] Fan, Z., Calsolaro, V., Atkinson, R.A., Femminella, G.D., Waldman, A., Buckley, C., Trigg, W., Brooks, D.J., Hinz, R. and Edison. P. (2016) Flutriciclamide [ ${ }^{18}$ F-GE180] PET: First in Human PET Study of Novel $3^{\text {rd }}$ Generation In Vivo Marker of Human Translocator Protein. Journal of Nuclear Medicine, 57, 1753-1759.

https://doi.org/10.2967/jnumed.115.169078

[37] Liu, G.-J., Middleton, R.J. and Banati, R.B. (2017) Subcellular Distribution of the 18 kDA Translocator Protein and Transcript Variant PBR-S in Human Cells. Gene, 613, 45-56. https://doi.org/10.1016/j.gene.2017.02.035

[38] Li, F., Liu, N., Kuhn, L.A., Garavito, R.M., Ferguson-Miller, S. (2016) Translocator Protein $18 \mathrm{kDa}$ (TSPO) : An Old Protein with New Functions? Biochemistry, 55, 2821-2831. https://doi.org/10.1021/acs.biochem.6b00142

[39] Jaremko, M., Jaremko, Ł., Jaipuria, G., Becker, S. and Zweckstetter, M. (2015) Structure of the Mammalian TSPO/PBR Protein. Biochemical Society Transactions, 43, 566-571. https://doi.org/10.1042/BST20150029

[40] Jaipuria, G., Leonov, A., Giller, K., Kumar Vasa, S., Jaremko, Ł., Jaremko, M., Linser, R., Becker, S. and Zweckstetter, M. (2017) Cholesterol-Mediated Allosteric Regulation of the Mitochondrial Translocator Protein Structure. Nature Communications, 8, 14893, https://doi.org/10.1038/ncomms14893

[41] Shoshan-Barmatz, V., Ben-Hail, D., Admoni, L., Krelin, Y. and Sharan Tripathi, S. 
(2025) The Mitochondrial Voltage Dependent Anion-Channel 1 in Tumor Cells. Biochimica et Biophysica Acta (BBA) - Biomembranes, 1848, 2547-2575. https://doi.org/10.1016/j.bbamem.2014.10.040

[42] Banati, R.B., Middelton, R.J., Chan, R., Hatty, C.R., Wai-Ying Kam, W., Quin, C., Graeber, M.B., Parma, A., Zahra, D., Callaghan, P., Fok, S., Howell, N.R., Gregoire, M., Szabo, A., Pham, T., Davis, E. and Liu, G.-J. (2014) Positron Emission Tomography and Functional Characterization of a Complete PBR/TSPO Knockout. Nature Communications, 5, 5452. https://doi.org/10.1038/ncomms6452

[43] Guilarte, T.R., Loth, M.K., Guariglia, S.R. (2016) TSPO Finds NOX2 in Microglia for Redox Homeostasis. Trends in Pharmacological Sciences, 37, 334-343. https://doi.org/10.1016/j.tips.2016.02.008

[44] Lartey, F.M., Ahn, G.-O., Ali, R., Rosenblum, S., Miao, Z., Arksey, N., Shen, B., Colomer, M.V., Rafat, M., Liu, H., Alejandre-Alcazar, M.A., Chem, J.W., Palmer, T., Chin, F.T., Guzman, R., Loo Jr., B.W. and Graves E. (2014) The Relationship between Serial $\left[{ }^{18} \mathrm{~F}\right]$ PBR06 PET Imaging of Microglial Activation and Motoric Function Following Stroke in Mice. Molecular Imaging and Biology, 16, 821-829. https://doi.org/10.1007/s11307-014-0745-0

[45] Jones, B.A., Beamer, M. and Ahmed, S. (2010) Fractalkine/CX3CL1: A Potential New Target for Inflammatory Diseases. Molecular Interventions, 10, 263-270. https://doi.org/10.1124/mi.10.5.3

[46] Corona, A.W., Huang, Y., O’Connor, J.C., Dantzer, R, Kelley, K.W., Popovich, P.G. and Godbout, J.P. (2010) Fractalkine Receptor CX3CR1 Deficiency Sensitizes Mice to the Behavioral Changes Induced by Lipopolysaccaride. Journal of Neuroinflammation, 7, 93. https://doi.org/10.1186/1742-2094-7-93

[47] Poniatowski, L.A., Woidasiewicz, P., Krawzyk, M., Sziukiewicz, D., Gasik, R., Kubaszewski, L. and Kurkowska-Jastrzebska, I. (2017) Analysis of the Role of CX3CL1 (Fractalkine) and Its Receptor CX3CR1 in Traumatic Brain and Spinal Cord Injury: Insight into Recent Advances in Actions of Neurochemokine Agents. Molecular Neurobiology, 54, 2167-2188. https://doi.org/10.1007/s12035-016-9787-4

[48] MacDowell, K.S., Caso, J.R., Martín-Hernández, D., Moreno, B.M., Madrigal, J.L.M., Micó, J.A., Leza, J.C. and García-Bueno, B. (2016) The Atypical Antipsychotic Paliperidone Regulates Endogenous Antioxidant/Anti-inflammatory Pathways in Rat Models of Acute and Chronic Restraint Stress. Neurotherapeutics, 13 833-843. https://doi.org/10.1007/s13311-016-0438-2

[49] Bazan, J.F., Bacon, H.B., Hardiman, G., Wang, W., Soo, K., Rossi, D., Greaves, D.R., Zlotnik, A. and Schall, T.J. (1997) A New Class of Membrane Bound Chemokine with a CX3C Motif. Nature, 385, 640-644. https://doi.org/10.1038/385640a0

[50] Mizoue, L.S., Sullivan, S.K., King, D.S., Kledal, T.N., Schwartz, T.W., Bacon, K.B. and Handel, T.M. (2001) Molecular Determinants of Receptor Binding and Signaling by the CX3C Chemokine Fractalkine. The Journal of Biological Chemistry, 276, 33906-33914. https://doi.org/10.1074/jbc.M101348200

[51] Roumen, L., Scholten, D.J., de Kruijf, P., de Esch, I.J.P., Leurs, R. and de Graaf, C. (2012) Computer-Aided Prediction of Chemokine Receptor-Ligand Interactions. Drug Discovery Today: Technologies, 9, e281-e291. https://doi.org/10.1016/j.ddtec.2012.05.002

[52] Mease, R., Yang, X., Foss, C. and Pomper, M. (2015) Radiosynthesis and Initial In Vivo Evaluation of $2{ }^{18}$ F-FBTTP, a Radiotracer Targeting CX3CR1. Journal of Nuclear Medicine, 56, 356.

[53] Arimont, M., Sun, S.-L., Leurs, R., Smit, M., de Esch, I. J. P. and de Graaf, C. (2017) 
Structural Analysis of Chemokine Receptor-Ligand Interactions. Journal of Medicinal Chemistry, 60, 4735-4779. https://doi.org/10.1021/acs.jmedchem.6b01309

[54] Gent, Y.Y.J., Weijer, K., Molthoff, C.F.M., Windhorst, A.D, Huisman, M.C., Smith, D.E.C., Kularatne, S.A., Jansen, G., Low, P.S., Lammertsma, A.A. and van der Laken, C.J. (2013) Evaluation of the Novel Folate Receptor Ligand $\left[{ }^{18} \mathrm{~F}\right]$ Fluoro-PEG-Folate for Macrophage Targeting in a Rat Model of Arthritis. Arthritis Research and Therapy, 15, R37.

[55] Al Jammaz, I., Al-Otaibi, B., Al-Rumayan, F., Al-Yanbawi, S., Amer, S. and Okarvi, S.M. (2014) Development and Preclinical Evaluation of ${ }^{124}$ I-Folate Conjugates for PET Imaging of Folate-Receptor Positive Tumors. Nuclear Medicine and Biology, 41, 457-463. https://doi.org/10.1016/j.nucmedbio.2014.03.013

[56] Chen, Q., Meng, X., McQuade, P., Rubin, D., Lin, S.-A., Zeng, Z., Haley, H., Miller, P., Trotter, D.G. and Low, P.S. (2016) Synthesis and Preclinical Evaluation of NOTA-Al ${ }^{18} \mathrm{~F}$ for PET Imaging. Molecular Pharmaceutics, 13, 1520-1527. https://doi.org/10.1021/acs.molpharmaceut.5b00989

[57] Wibowo, A., Singh, M., Reeder, K.M., Carter, J.J., Kovach, A.R., Meng, W., Ratnam, M., Zhang, F. and Dann, C.E. (2013) Structures of Human Folate Receptors Reveal Biological Trafficking States and Diversity in Folate and Antifolate Recognition. Proceedings of the National Academy of Sciences, 110, 15180-15188. https://doi.org/10.1073/pnas.1308827110

[58] Chen, C., Ke, J., Zhou, E., Ji, W., Brunzelle, J.S., Li, J., Yong, E.-L., Xu, H.E. and Melcher, K. (2013) Structural Basis for Molecular Recognition of Folic Acid by Folate Receptors. Nature, 500, 486-490. https://doi.org/10.1038/nature12327

[59] Müller, C. (2013) Folate-Based Radiotracer for PET Imaging-Update and Perspectives. Molecules, 18, 5005-5031. https://doi.org/10.3390/molecules 18055005

[60] Gavish, M. Bachman, I., Shoukrun, R., Katz, Y., Veenman, L., Weisinger, G. and Weizman, W. (1999) Enigma of the Peripheral Benzodiazepine Receptor. Pharmacological Reviews, 51, 629-650.

[61] Venneti, S. Lopreti, B.J., Wiley, C.A. (2013) Molecular Imaging of Microglia/Macrophages in the Brain. GLIA, 61, 10-23. https://doi.org/10.1002/glia.22357

[62] Anholt, R.R., De Souza, E.B., Oster-Granite, M.L. and Snyder, S.H. (1985) Peripheral-Type Benzodiazepine Receptors: Autoradiographic Localization in Whole-Body Sections of Neonatal Rats. Journal of Pharmacology and Experimental Therapeutics, 233, 517-526.

[63] LeFur, G., Perrier, M.L., Vaucher, N., Imbault, F., Flamier, A., Benavides, J., Uzan, A., Renault, C., Dubroeuq, M.C. and Guérémy, C. (1983) Peripheral Benzodiazepine Binding Sites: Effect of PK11195 (1-(2-Chlorophenyl)-N-Methyl-N-(1-Methylpropyl)-3Isoquinoline Carboxamide: I. In Vitro Studies. Life Science, 32, 1839-1847. https://doi.org/10.1016/0024-3205(83) 90062-0

[64] Syapin, P.J. and Skolnick, P. (1979) Characterization of Benzodiazepine Binding Sites in Cultured Cells of Neural Origin. Journal of Neurochemistry, 32, 1047-1051. https://doi.org/10.1111/j.1471-4159.1979.tb04592.x

[65] Marangos, P.J., Patel, J., Boulenger, J.-P. and Clark-Rosenberg, R. (1982) Characterization of Peripheral-Type Benzodiazepine Binding Sites in Brain Using $\left[{ }^{3} \mathrm{H}\right]$ Ro5-4864. Molecular Pharmacology, 22, 26-32.

[66] Marginedas-Freixa, I., Hattab, C., Bouyer, G., Halle, F., Chene, A., Lefevre, S.D., Cambot, M., Cueff, A., Schmitt, M., Gamain, B., Lacapere, J.J., Egee, S., Bihel, F., Le Vam Kim, C. and Ostuni, M.A. (2016) TSPO Ligands Stimulate ZnPPIX and ROS Accumulation Leading to the Inhibition of P. Falciparum Growth in Human Blood. 
Scientific Reports, 6, Article 33516. https://doi.org/10.1038/srep33516

[67] Bernardi, P. and Di Lisa, F. (2015) The Mitochondrial Permeability Transition Pore: Molecular Nature and Role as a Target in Cardioprotection. Journal of Molecular and Cellular Cardiology, 78, 100-106. https://doi.org/10.1016/j.yjmcc.2014.09.023

[68] Fancelli, D., Abate, A., Amici, R., Bernardi, P., Ballarini, M., Cappa, A., Carezi, G., Colombo, C., Di Lisa, F., Dondio, G., Gagliardi, S., Milanesi, E., Minucci, S., Pain, G., Pelicci, P.G., Saccani, A., Storto, M., Thaler, F., Varasi, M., Vill, A.M. and Plyte, S. (2014) Cinnamic Anilides as New Mitochondrial Permeability Transition Pore Inhibitors Endowed with Ischemia-Reperfusion Injury Protective Effect In Vivo. Journal of Medicinal Chemistry, 57, 5333-5347. https://doi.org/10.1021/jm500547c

[69] Elustondo, P.A., Nichols, M., Negoda, A., Thirumaran, T., Zakharian, E., Robertson, G.S. and Pavlov, E.V. (2016) Mitochondrial Permeability Transition Pore Induction Is Linked to Formation of the Complex of ATPase C-Subunit, Polyhydroxybutyrate and Inorganic Polyphosphate. Cell Death Discovery, 2, 16070.

https://doi.org/10.1038/cddicovery.2016.70

[70] Papadopoulos, V., Aghazadeh, Y., Fan, J., Campioli, E., Zirkin, B. and Midzak, A. (2015) Translocator Protein-Mediated Pharmacology of Cholesterol Transport and Steroidogenesis. Molecular and Cellular Endocrinology, 408, 90-98.

https://doi.org/10.1016\{j.mce.2015.03.014

[71] Bernardi, P., Rasola, A., Forte, M., and Lippe, G. (2015) The Mitochondrial Permeability Transition Pore: Channel Formation by F-ATP Synthase, Integration in Signal Transduction, and Role in Pathophysiology. Physiological Reviews, 95, 1111-1155. https://doi.org/10.1152/physrev.00001.2015

[72] Yasin, N., Veenman, L., Singh, S., Azrad, L., Bode, J. and Vainstein, A., Caballero, B., Marek, I. and Gavish, M. (2017) Classical and Novel TSPO Ligands for the Mitochondrial TSPO Can Modulate Nuclear Gene Expression. Implications for Mitochondrial Retrograde Signaling. International Journal of Molecular Sciences, 18, 786. https://doi.org/10.3390/ijms18040786

[73] Zhang, J. (2015) Mapping Neuroinflammation in Frontotemporal Dementia with Molecular PET Imaging. Journal of Neuroinflammation, 12, 108. https://doi.org/10.1186/s12974-015-0236-5

[74] Guo, Q., Owen, W.R., Rabiner, E.A., Turkheimer, F.E. and Gunn, R.N. (2012) Identifying Improved TSPO PET Imaging Probes through Biomathematics: The Impact of Multiple TSPO Binding Site In Vivo. Neuroimage, 60, 902-910. https://doi.org/10.1016/j.neuroimage.2011.12.078

[75] Srivasta, P., Kaul, A., Ojha, H., Kumar, P., Tiwari, A.K. (2016) Design, Synthesis and Biological Evaluation of Methyl-2-(2-(5-Bromo-Benzoxazolone) Acetamido)3-(1H Indol-3-yl) Propanoate: TSPO Ligand for SPECT. RSC Advances, 6, 1114491. https://doi.org/10.1039/C6RA19514H

[76] Braestrup, C., Albrechtsen, R. and Squires, R.F. (1977) High Densities of Benzodiazepine Receptors in Human Cortical Areas. Nature, 269, 702-704.

https://doi.org/10.1038/269702a0

[77] Braestrup, C. and Squires, R.F. (1977) Specific Benzodiazepine Receptors in Rat Brain Characterized by High-Affinity $(3 \mathrm{H})$ Diazepam Binding. Proceedings of the National Academy of Sciences, 74, 3805-3809. https://doi.org/10.1073/pnas.74.9.3805

[78] Awad, M. and Gavish, M. (1991) Peripheral-Type Benzodiazepine Receptors in Human Cerebral Cortex, Kidney, and Colon. Life Sciences, 49, 1155-1161. https://doi.org/10.1016/0024-3205(91) 90562-P 
[79] Scarf, A.M. and Kassiou, M. (2011) The Translocator Protein. Journal of Nuclear Medicine, 52, 677-680. https://doi.org/10.2967/jnumed.110.086629

[80] Airas, L., Rissanen, E. and Rinne, J.O. (2015) Imaging Neuroinflammation in Multiple Sclerosis Using TSPO PET. Clinical and Translational Imaging, 3, 461-473. https://doi.org/10.1007/s40336-015-0147-6

[81] Price, G.W., Ahier, R.G., Hume, S.P., Myers, R. and Manjil, L. and Cremer, J.E., Luthra, S.K., Pascali, C., Pike, V. and Frackowiak, R.S.J. (1990) In Vivo Binding to Peripheral Benzodiazepine Binding Sites in Lesioned Rat Brain: Comparison between $\left[{ }^{3} \mathrm{H}\right] \mathrm{PK} 11195$ and $\left[{ }^{18} \mathrm{~F}\right] \mathrm{PK} 14105$ as Markers for Neuronal Damage. Journal of Neurochemistry, 55, 175-185. https://doi.org/10.1111/j.1471-4159.1990.tb08836.x

[82] Beurdeley-Thomas, A., Miccoli, L., Oudard, S., Dutrillaux, B. and Poupon, M.F. (2000) The Peripheral Benzodiazepine Receptor: A Review. Journal of Neuro-Oncology, 46, 45-56. https://doi.org/10.1023/A:1006456715525

[83] Henkel, K., Karitzky, J., Schmid, M., Mader, I., Glatting, G., Unger, J.W., Neumaier, B., Ludolph, A.C., Reske, S.N. and Landwehrmeyer, G.B. (2004) Imaging of Activated Microglia and $\left[{ }^{11} \mathrm{C}\right] \mathrm{PK} 11195$ in Corticobasal Degeration. Movement Disorders, 19, 817-824. https://doi.org/10.1002/mds.20040

[84] Scott, G., Hellyer, P.J., Ramlackhansingh, A.F., Brooks, D.J., Maths, P.M. and Sharp, D.J. (2015) Thalamic Information after Brain Trauma is Associated with Thalamo Cortical White Matter Damage. Journal of Neuroinflammation, 12, 224. https://doi.org/10.1186/s12974-015-0445-y

[85] Declercq, L.D., Vandenberghe, R., van Laere, K., Verbruggen, A. and Bormans, G. (2016) Drug Development in Alzheimer's Disease: The Contribution of PET and SPECT. Frontiers in Pharmacology, 7, Article 88. https://doi.org/10.3389/fphar.2016.00088

[86] Doorduin, J., Klein, H.C., Dierckx, R.A., James, M., Kassiou, M. and de Vries, E.F.J. (2009) $\left[{ }^{11} \mathrm{C}\right]-D P A-713$ and $\left[{ }^{18} \mathrm{~F}\right]-\mathrm{DPA}-714$ as New PET Tracers for TSPO. A Comparison with $\left[{ }^{11} \mathrm{C}\right]-(R)-\mathrm{PK} 11195$ in a Rat Model of Herpes Encephalitis. Molecular Imaging and Biology, 11, 386-398. https://doi.org/10.1007/s11307-009-0211-6

[87] Varrone, A., Mattsson, P., Forsberg, A., Takano, A., Nag, S., Gulyas, B., Borg, J., Boellaard, R., Al-Tawil, N., Eriksdotter, M., Zimmermann, T., Schultze-Mosgau, M., Thiele, A., Hoffmann, A., Lammertsma, A.A. and Halldin, C. (2013) In Vivo Imaging of the $18 \mathrm{kDa}$ Translocator Protein (TSPO] with $\left[{ }^{18} \mathrm{~F}\right]$ FEDAA1106 and PET Does Not Show Increased Binding in Alzheimer's Disease Patients. European Journal of Nuclear Medicine and Molecular Imaging, 40, 921-931.

https://doi.org/10.1007/s00259-013-2359-1

[88] Mabrouk, R., Strafella, A.P., Knezevic, D., Ghadery, C., Mizrahi, R., Gharegazlou, A., Koshimori, Y., Houle, S. and Rusjan, P. (2017) Feasibility Study of TSPO Quantification with $\left[{ }^{18} \mathrm{~F}\right] \mathrm{FEPPA}$ Using Population-Based Input Function. PLoS ONE, 12, e0177785. https://doi.org/10.1371/journal.pone.0177785

[89] Suridjan, I., Rusjan, P.M., Voineskos, A.N., Selvanathan, T., Setiawan, E., Strafella, A.P., Wilson, A.A., Meyer, J.H., Houle, S. and Mizrahi, R. (2014) Neuroinflammation in Healthy Aging: A PET Study Using a Novel Translocator Protein $18 \mathrm{kDa}$ (TSPO) Radioligand, $\left[{ }^{18} \mathrm{~F}\right]$ FEPPA. Neuroimage, 84, 868-875. https://doi.org/10.1016/j.neuroimage.2013.09.021

[90] Suridjan, I., Pollock, B.G., Verhoeff, N.P.L.G., Voineskos, A.N., Chow, T., Rusjan, P.M., Lobaugh, N.J., Houle, S., Mulsant, B.H. and Mizrahi, R. (2015) In Vivo Imaging of Grey and White Matter Neuroinflammation of Alzheimer's Disease: Positron Emission Tomography Study with a Novel Radioligand $\left[{ }^{18} \mathrm{~F}\right]$ FEPPA. Molecular 
Psychiatry, 20, 1579-1587. https://doi.org/10.1038/mp.2015.1

[91] Koshimori, Y., Ko, J.-H., Mizrahi, R., Rusjan, P., Mabrouk, R., Jacobs, M.F. Christopher, L., Hamani, C., Lang, A.E., Wilson, A.A., Houle, S. and Strafella, A.P. (2015) Imaging Striatal Microglial Activation in Patients with Parkinson's Disease. PLoS ONE, 10, e0138721. https://doi.org/10.1371/journal.pone.0138721

[92] Mueller-Gaertner, H.W., Links, J.M., Prince, J.L., Bryan, R.N., McVeigh, E., Leal, J.P., Davazikos, Ch. and Frost, J. (1992) Measurement of Radiotracer Concentration in Brain Gray Matter Using Positron Emission Tomography: MRI-Based Correction for Partial Volume Effects. Journal of Cerebral Blood Flow \& Metabolism, 12, 571-583. https://doi.org/10.1038/jcbfm.1992.81

[93] Venneti, S., Wang, G., Nguyen, J. and Wiley, C.A. (2008) The Positron Emission Tomography Ligand DAA1106 Binds with High Affinity to Activated Microglia in Human Neurological Disorders. Journal of Neuropathology \& Experimental Neurology, 67, 1001-1010. https://doi.org/10.1097/NEN.0b013e318188b204

[94] Mirzaei, N., Tang, S.P., Asworth, S., Coello, C., Plisson, C., Passchier, J., Selvaraj, V., Tyacke, R.J., Nutt, D.J. and Sastre, M. (2016) In Vivo Imaging of Microglial Activation by Positron Emission Tomography with $\left[{ }^{11} \mathrm{C}\right]$ PBR28 in the 5XFAD Model of Alzheimer Disease. GLIA, 64, 993-1006.

[95] Wadsworth, H., Jones, P.A., Chau, W.-F., Durrant, C., Fouladi, N., Passmore, J., O’Shea, D., Wynn, D., Morrison-Iveson, V., Ewan, A., Thaning, M., Mantzilas, D., Gausemel, I., Khan, I., Black, A., Avory, M. and Trigg, W. (2012) $\left[{ }^{18} \mathrm{~F}\right] \mathrm{GE}-180$ : A Novel Fluorine 18 Labelled PET Tracer for Imaging Translocator Protein $18 \mathrm{kDa}$ (TSPO). Bioorg and Medicinal Chemistry Letters, 22, 1308-1313. https://doi.org/10.1016/j.bmcl.2011.12.084

[96] Chau, W.-F., Black, A.M.A., Clarke, A., Durrant, C., Gausemel, I., Khan, I., Mantzilas, D., Oulie, I., Rogstad, A., Trigg, W. and Jones, P.A. (2015) Exploration of the Impact of Stereochemistry on the Identification of the Novel Translocator Protein PET Imaging Agent $\left[{ }^{18} \mathrm{~F}\right]$ GE180. Nuclear Medicine and Biology, 42, 711-719. https://doi.org/10.1016/j.nucmedbio.2015.05.004

[97] Feeney, C., Scott, G., Raffel, J., Roberts, S., Coello, C., Jolly, A., Searle, G., Goldstone, A.P., Brooks, D.J., Nicholas, R.S., Trigg, W., Gunn, R.N. and Sharp, D.J. (2016) Kinetic Analysis of the Translocator Protein Positron Emission Tomography Ligand $\left[{ }^{18} \mathrm{~F}\right] \mathrm{GE}-180$ in the Human Brain. European Journal of Nuclear Medicine and Molecular Imaging, 43, 2201-2210. https://doi.org/10.1007/s00259-016-3444-Z

[98] Owen, D.R., Guo, Q., Kalk, N.J., Colasanti, A., Kalogiannopoulou, D., Dimber, R., Lewis, Y.L., Libri, V., Barletta, J., Ramada-Magalhaes, J., Kamalakaran, A., Nut, D.J., Passchier, J., Matthews, P.M., Gunn, R.N. and Rabiner, E.A. (2014) Determination of $\left[{ }^{11} \mathrm{C}\right]$ PBR28 Binding Potential In Vivo: A First Human TSPO Blocking Study. Journal of Cerebral Blood Flow \& Metabolism, 34, 989-994. https://doi.org/10.1038/jcbfm.2014.46

[99] Lassen, N.A., Bartenstein, P.A., Lammertsma, A.A., Prevett, M.C. Turton, D.R., Luthra, S.K., Osman, S., Bloomfield, P.M., Jones, T., Patsalos, D.R., Connell, T.O., Duncan, J.S. and Andersen, V. (1995) Benzodiazepine Receptor Quantification In Vivo in Humans Using $\left[{ }^{11} \mathrm{C}\right]$ Flumazenil and PET: Application of the Steady State Principle. Journal of Cerebral Blood Flow \& Metabolism, 15, 152-165. https://doi.org/10.1038/jcbfm.1995.17

[100] Okubo, T., Yoshikawa, R., Chaki, S., Okuyama, S. and Nakatzato, A. (2004) Design, Synthesis and Structure-Activity Relationships of Novel Tetracyclic Compounds as Peripheral Benzodiazepine Receptor Ligands. Bioorganic \& Medicinal Chemistry, 12, 3569-3580. https://doi.org/10.1016/j.bmc.2004.04.025 
https://doi.org/10.1016/j.bmc.2003.10.050

[101] O’Shea, D., Ahmad, R., Arstad, E., Avory, M., Chau, W.F., Durrant, C., Hirani, E., Jones, P.A., Khan, I., Luthra, S.K., Mantzilas, D., Morrison-Iveson, V., Passmore, J., Robins, E.G., Shan, B., Wadsworth, H., Walton, S., Zhao, Y. and Trigg, W. (2013) Exploration of the Structure Activity Relationship of a Novel Tetracyclic Class of TSPO Ligands-Potential Positron Emitting Tomography Imaging Agents. Bioorganic \& Medicinal Chemistry Letters, 23, 2368-2372.

https://doi.org/10.1016/j.bmcl.2013.02.057

[102] Ikawa, M., Lohith, T.G., Shrestha, S., Telu, S., Zoghbi, S.S., Castellano, S., Taliani, S., da Settimo, F., Fujita, M., Pike, V.W. and Innis, R.B. (2017) ${ }^{11}$ C-ER176, a Radioligand $18 \mathrm{kDa}$ Translocator Protein (TSPO) Has Adequate Sensitivity to Robustly Image All Three Affinity Genotypes in Human Brain. Journal of Nuclear Medicine, 58, 320-325.

[103] Andrews, S.P. and Cox, R.J. (2016) Small Molecule CXCR Antagonists. Journal of Medicinal Chemistry, 59, 2894-2917. https://doi.org/10.1021/acs.jmedchem.5b01337

[104] Pawing, L., Klasen, C., Weber, C., Bernhagen, J. and Noels, H. (2015) Diversity and Inter-Connections in the CXCR4 Receptor/Ligand Family: Molecular Perspectives. Frontiers in Immunology, 6, Article 429.

[105] Cederblad, L., Rosengren, B., Ryberg, E. and Hermansson, N.-O. (2016) AZD8797 is an Allosteric Non-Competitive Modulator of the Human CX3CR1 Rreceptor. Biochemical Journal, 473, 641-647. https://doi.org/10.1042/BJ20150520

[106] Bachelerie, F., Ben-Baruch, A., Burkhardt, A.M., Combadiere, C., Farber, J.M., Graham, G.J., Goruk, R. Sparre-Ulrich, A.H., Locati, M., Luster, A.D., Matovani, A., Matsushima, K., Murphy, P.M., Nibbs, R., Nomiyama, H., Power, C.A., Proudfoot, A.E.I., Rosenkilde, M.M., Rot, A., Sozzani, S., Thelen, M., Yoshie, O. and Zlotnik A. (2014) International Union of Basic and Clinical Pharmacology LXXXIX. Update on the Extended Family of Chemokine Receptors and Introducing a New Nomenclature for Atypical Chemokine Receptors. Pharmacological Reviews, 66, 1-79. https://doi.org/10.1124/pr.113.007724

[107] Harrison, J.K., Jiang, Y., Chen, S., Xia, Y., Maciejewski, D., McNamara, R.K., Streit, W.J., Salafranca, M.N., Adhikari, S., Thompson, D.A., Botti, P., Bacon, K.B. and Feng, L. (1998) Role for Neuronally Derived Fractalkine in Mediating Interactions Between Neurons and CX3CR1-Expressing Microglia. Proceedings of the National Academy of Sciences, 95, 10896-10901. https://doi.org/10.1073/pnas.95.18.10896

[108] Wolf, Y., Yona, S., Kim, K.-W. and Jung, S. (2013) Microglia Seen from the CX3CR. Frontiers in Cellular Neuroscience, 7, Article 26.

[109] Karlstrom, S., Nordvall, G., Sohn, D., Hettman, A., Turek, D., Ahlin, K., Kers, A., Claesson, M., Slivo, C., Lo-Alfredsson, Y., Petersson, C., Bessidskaia, G., Svensson, P.H., Rein, T., Jerning, E., Malmberg, A., Ahlgen, C., Ray, C., Vares, L., Ivanov, V. and Johansson, R. (2013) Substituted 7-Amino-5-thio-thiazolo[4, 5-d]pyrimidines as Potent and Selective Antagonists of the Fractalkine Receptor (CX3CR1). Journal of Medicinal Chemistry, 56, 3177-3190. https://doi.org/10.1021/jm3012273

[110] Tang, Z., Gan, Y., Liu, Q.Yin, J.-X., Liu, Q., Shi, J. and Shi, F.-D. (2014) CX3CR Deficiency Supresses Activation and Neurotoxicity of Microglia/Macrophage in Experimental Ischemic Stroke. Journal of Inflammation, 11, 26.

[111] Maciejewski-Lenoir, D., Chen, S., Feng, L., Maki, R. and Bacon, K.B. (1999) Characterization of Fractalkine in Rat Brain Cells: Migratory and Activating Signals for CX3CR-1 Expressing Microglia. The Journal of Immunology, 163, 1628-1635. 
[112] Steen, A., Larsen, O., Thiele, S. and Rosenkilde, M.M. (2014) Biased and G-Protein Independent Signaling of Chemokine Receptors. Frontiers and Immunology, 5, Article 277. https://doi.org/10.3389/fimmu.2014.00277

[113] Malmquist, J. and Ström, P. (2012) Multiple Labeling of a Potent CX3CR1 Antagonist for the Treatment of Multiple Sclerosis. Journal of Labelled Compounds and Radiopharmaceuticals, 55, 387-392. https://doi.org/10.1002/jlcr.2958

[114] Pomper, M., Mease, R.C., Xing, Y. and Foss, C. (2016) Radiofluorinated 7-Amino5-thio-thiazolo[4,5-d]pyrimidines for Imaging Fractalkine Receptor (CX3CR1). WO2016200939 A1.

[115] Steinfeld, R., Grapp, M., Kraetzner, R., Dreha-Kulaczewski, S., Helms, G., Dechent, P., Wevers, R., Gro, S. and Gärtner, J. (2009) Folate Receptor Alpha Defect Causes Cerebral Folate Transport Deficiency: A Treatable Neurodegenerative Disorder Associated with Disturbed Myelin Metabolism. The American Journal of Human Genetics, 85, 354-363. https://doi.org/10.1016/j.ajhg.2009.08.005

[116] Doucette, M.M. and Stevens, V.L. (2001) Folate Receptor Function is Regulated in Response to Different Cellular Growth Rates in Cultured Mammalian Cells. Journal of Nutrition, 131, 2819-2825.

[117] Yi, J.S. (2016) Folate Receptor-Targeted Diagnostics and Therapeutics for Inflammatory Diseases. Immune Network, 16, 337-343.

https://doi.org/10.4110/in.2016.16.6.337

[118] Farkas, R., Siwowska, K., Ametamey, S.M., Schibli, R., van der Meulen, N.P. and Müller C. (2016) ${ }^{64} \mathrm{Cu}$ and ${ }^{68} \mathrm{Ga}$ Based PET Imaging of Folate Receptor Positive Tumors: Development and Evaluation of an Albumin Binding NODAGA-Folate. Molecular Pharmaceutics, 13, 1979-1987. https://doi.org/10.1021/acs.molpharmaceut.6b00143

[119] Han, W., Zaynagetdinov, R., Yull, F.E., Polosukhin, V.V., Gleaves, L.A., Tanjore, H., Young, L.R., Peterson, T.E., Manning, H.C., Prince, L.S. and Blackwell, T.S. (2015) Molecular Imaging of Folate Receptor Positive Macrophages during Acute Lung Inflammation. American Journal of Respiratory Cell and Molecular Biology, 53, 50-59.

[120] Puig-Kröger, A., Sierra-Filardi, E., Dominguez Soto, A., Samaniego, R., Corcuera, M.T., Gomez-Aguado, F., Ratnam, M., Sanchez-Mateos, P. and Corbi, A.L. (2009) Folate Receptor $\beta$ Is Expressed by Tumor Associated Macrophages and Constitutes a Marker for M2 Anti-Inflammatory/Regulatory Macrophages. Cancer Research, 69, 9395-9403. https://doi.org/10.1158/0008-5472.CAN-09-2050

[121] Mayanil, C.S., Siddiqui, M.R. and Tomita, T. (2014) Novel Functions of Folate Receptor Alpha in CNS Development and Diseases. Neuroscience Discovery, 2, 5. http://www.hoajonline.com/journals/pdf/2052-6946-2-5.pdf

[122] Boshnjaku, V., Shim, K.-W., Tsurubuchi, T., Ichi, S., Szany, E.V., Xi, G., Mania-Farnell, B., Mclone, D.G., Tomita, T. and Mayanil, C.S. (2012) Nuclear Localization of Folate Receptor Alpha: A New Role as a Transcription Factor. Scientific Reports, 2, 980. https://doi.org/10.1038/srep00980

[123] Gordon N. (2009) Cerebral Folate Deficiency. Developmental Medicine and Child Neurology, 51, 180-182. https://doi.org/10.1111/j.1469-8749.2008.03185.x

[124] O’Shannessy, D.J., Somers, E.B., Wang, L.-C., Wang, H. and Hsu. R. (2015) Expression of Folate Receptors Alpha and Beta in Normal and Cancerous Gynecologic Tissues: Correlation of Expression of Beta Isoform with Macrophage Markers. Journal of Ovarian Research, 8, 29. https://doi.org/10.1186/s13048-015-0156-0

[125] Van der Heijden, V.W., Oerlemans, R., Dijkmans, B.A.C., Qi, H., van der Laken, 
C.J., Lems, W.F., Jackman, A.L., Kraan, M.C., Tak, P.P., Ratnam, M. and Jansen, G. (2009) Folate Receptor $\beta$ as a Potential Delivery Route for Novel Folate Antagonists to Macrophages in the Synovial Tissue of Rheumatic Arthritis Patients. Arthritis \& Rheumatism, 60, 12-21. https://doi.org/10.1002/art.24219

[126] Jager, N.A., Westra, J., Golestani, R., van Dam, G.M., Low, P.S., Tio, R.A., Slart, R.H.J.A., Boersma, H.H., Bijl, M. and Zeebregts, C.J. (2014) Folate Receptor $\beta$ Imaging Using ${ }^{99 \mathrm{~m}} \mathrm{Tc}$ Folate to Explore Distribution of Polarized Macrophage Populations in Human Atherosclerotic Plaque. Journal of Nuclear Medicine, 55, 1945-1951.

https://doi.org/10.2967/jnumed.114.143180

[127] Nagayoshi, R., Nagai, T., Matsushit, K., Sato, K., Sunahara, N., Matsuda, T., Nakamura, T., Komiya, S., Onda, M. and Matsuyama, T (2005) Effectiveness of Anti-Folate Receptor-Beta Antibody Conjugated with Truncated Pseudomonas Exotoxin in the Targeting of Rheumatoid Arthritis Synovial Macrophages. Arthritis Rheum, 52, 2666-2675. https://doi.org/10.1002/art.21228

[128] Spector, R. and Lorenzo, A.V. (1975) Folate Transport by Choroid Plexus In Vitro. Science, 187, 540-542. https://doi.org/10.1126/science.1167256

[129] Ramaekers, V., Sequeira, J.M. and Quadros, E.V. (2013) Clinical Recognition and Aspects of the Cerebral Folate Deficiency Syndromes. Clinical Chemistry and Laboratory Medicine, 51, 497-511. https://doi.org/10.1515/cclm-2012-0543

[130] Bettio, A., Honer, M., Müller, C., Brühlmeier, M., Müller, U., Schibli, R., Groehn, V., Schubiger, P.A. and Ametamey, S.M. (2006) Synthesis and Preclinical Evaluation of a Folic Acid Derivative Labeled with ${ }^{18} \mathrm{~F}$ for PET Imaging of Folate Receptor Positive Tumors. Journal of Nuclear Medicine, 47, 1153-1160.

[131] Schieferstein, H. and Ross, T.L. (2013) ${ }^{18}$ F-Labeled Folic Acid Derivatives for Imaging of the Folate Receptor via Positron Emission Tomography. Journal of Labelled Compounds and Radiopharmaceuticals, 56, 432-440.

https://doi.org/10.1002/jlcr.3104

[132] Ross, T.L., Honer, M., Lam, P.Y., Mindt, T.L., Groehn, V., Schibli, R., Schubiger, P.A. and Ametamey, S.M. (2008) Fluorine-18 Click Radiosynthesis and Preclinical Evaluation of a New ${ }^{18} \mathrm{~F}$-labeled Folic Acid Derivative. Bioconjugate Chemistry, 19, 2462-2470. https://doi.org/10.1021/bc800356r

[133] Müller, C. and Schibli, R. (2013) Prospects in Folate Receptor-Targeted Radionuclide Therapy. Frontiers in Oncology, 3, Article 249.

https://doi.org/10.3389/fonc.2013.00249

[134] Siwowska, H., Haller, S., Bortoli, F., Benesova, M., Groehn, V., Berhard, P., Schibli, R. and Müller, C. (2017) Preclinical Comparison of Albumin-Binding Radiofolates: Impact of Linker Entities on the In Vitro and In Vivo Properties. Molecular Pharmaceutics, 14, 523-532. https://doi.org/10.1021/acs.molpharmaceut.6b01010

[135] Fischer, C.R., Muller, C., Reber, J., Muller, A., Kramer, S.D., Ametamey, S.M. and Schibli, R. (2012) $\left[{ }^{18}\right.$ F]Fluoro-Deoxy-Glucose Folate: A Novel PET Radiotracer with Improved In Vivo Properties for Folate Receptor Targeting. Bioconjugate Chemistry, 23, 805-813. https://doi.org/10.1021/bc200660z

[136] Ross, T.L., Honer, M., Muller, C., Groehn, V., Schibli, R. and Ametamey, S.M. (2010) A New ${ }^{18}$ F-Labeled Folic Acid Derivative with Improved Properties for the PET Imaging of Folate Receptor-Positive Tumors. Journal of Nuclear Medicine, 51, 1756-1762. https://doi.org/10.2967/jnumed.110.079756

[137] Pissarek M. (2017) Small Molecule-Assisted Brain PET: Approaches to Imaging of Conformational Diseases. World Journal of Neuroscience, 7, 106-139.

https://doi.org/10.4236/wjns.2017.71010 
[138] Damont, A., Medran-Navarrete, V., Cacheux, F., Kuhnast, B., Pottier, G., Bernards, N., Marguet, F., Puech, F., Boisgard, R. and Dollé, F. (2015) Novel Pyrazololo[1, 5-a]Pyrimidines as Translocator Protein $18 \mathrm{kDa}$ (TSPO) Ligands: Synthesis, In Vitro Biological Evaluation, $\left[{ }^{18} \mathrm{~F}\right]$-Labeling, and In Vivo Neuroinflammation PET Images. Journal of Medicinal Chemistry, 58, 7449-7464.

https://doi.org/10.1021/acs.jmedchem.5b00932

[139] Dupont, A.-C., Largeau, B., Ribeiro, M.J.S., Guilloteau, D., Tronel, C. and Arlicot, N. (2017) Translocator Protein $18 \mathrm{kDa}$ (TSPO) Positron Emission Tomography Imaging (PET) and Its Clinical Impact in Neurodegenerative Diseases. International Journal of Molecular Sciences, 18, 785. https://doi.org/10.3390/ijms18040785

[140] Hilmer, A.T., Holden, D., Fowles, K., Nabusi, N., West, B.L., Carson, R.E. and Cosgrove K.P. (2017) Microglial Depletion and Activation. A $\left[{ }^{11} \mathrm{C}\right]$ PBR28 PET Study in Nonhuman Primates. EJNMMI Research, 7, 59.

http://doi.org/10.1186/s13550-017-0305-0

[141] McManus, R.M. and Heneka, M.T. (2017) Role of Neuroinflammation in Neurodegeneration: New Insights. Alzheimer's Research and Therapy, 9, 14.

https://doi.org/10.1186/s13195-017-0241-2

[142] Sheridan, G.K. and Murphy, K.J. (2013) Neuron-Glia Crosstalk in Health and Disease: Fractalkine and CX3CR1 Take Centre Stage. Open Biology, 3, 130181. http://doi.org/10.1098/rsob.130181

[143] Paolicelli, R.C., Bisht, K. and Tremblay, M.-E. (2014) Fractalkine Regulation of Microglial Physiology and Consequences on the Brain and Behavior. Frontiers in Cellular Neuroscience, 8, Article 129. https://doi.org/10.3389/fncel.2014.00129 


\section{Abbreviations}

a.a.r.

Amino acid residues

AKR

Atypical chemokine receptors

ANT

Adenine nucleotide transporter

$\mathrm{CD}$

Cluster of differentiation

CBR

Central benzodiazepine receptor

CNS

Central nervous system

CX3CR Subgroup of chemokine receptors characterized by presence of three other a.a.r. between to cysteines in the $\mathrm{N}$-terminus of the receptor

GPI

Glycosyl-phosphatidylinositol

FAD

Familial Alzheimer's disease

FBA

Fluorobenzylamine

FR

Folate receptor

FKN

Fractalkine

$\mathrm{HAB}$

High affinity binder

KB31 cells

Nasopharyngeal epidermal carcinoma cells

LAB

Low affinity binder

$\mathrm{MAB}$

Mixed affinity binder

$5 \mathrm{MTFH}$

5-Methyltetrahydrofolate

MPTP

Mitochondrial permeability transition pore

PBR

Peripheral type benzodiazepine receptor

PCFT

Proton-coupled folate transporter

$\mathrm{PD}$

Parkinson disease

PEG

Polyethylenglycol

PET

Positron emission tomography

RFC Reduced folate transporter

SPECT

Single photon emission tomography

$5 \mathrm{TM}$

Five transmembrane domains

TACE Tumor necrosis factor alpha converting enzyme

TSPO Translocator protein $18 \mathrm{kDa}$

VDAC Voltage-dependent anion channel 